\title{
Volcanic ash fall hazard and risk
}

Technical background paper for the UN-ISDR Global Assessment Report on Disaster Risk Reduction 2015

A report by Global Volcano Model ${ }^{1}$ and the International Association of Volcanology and Chemistry of the Earth's Interior ${ }^{2}$
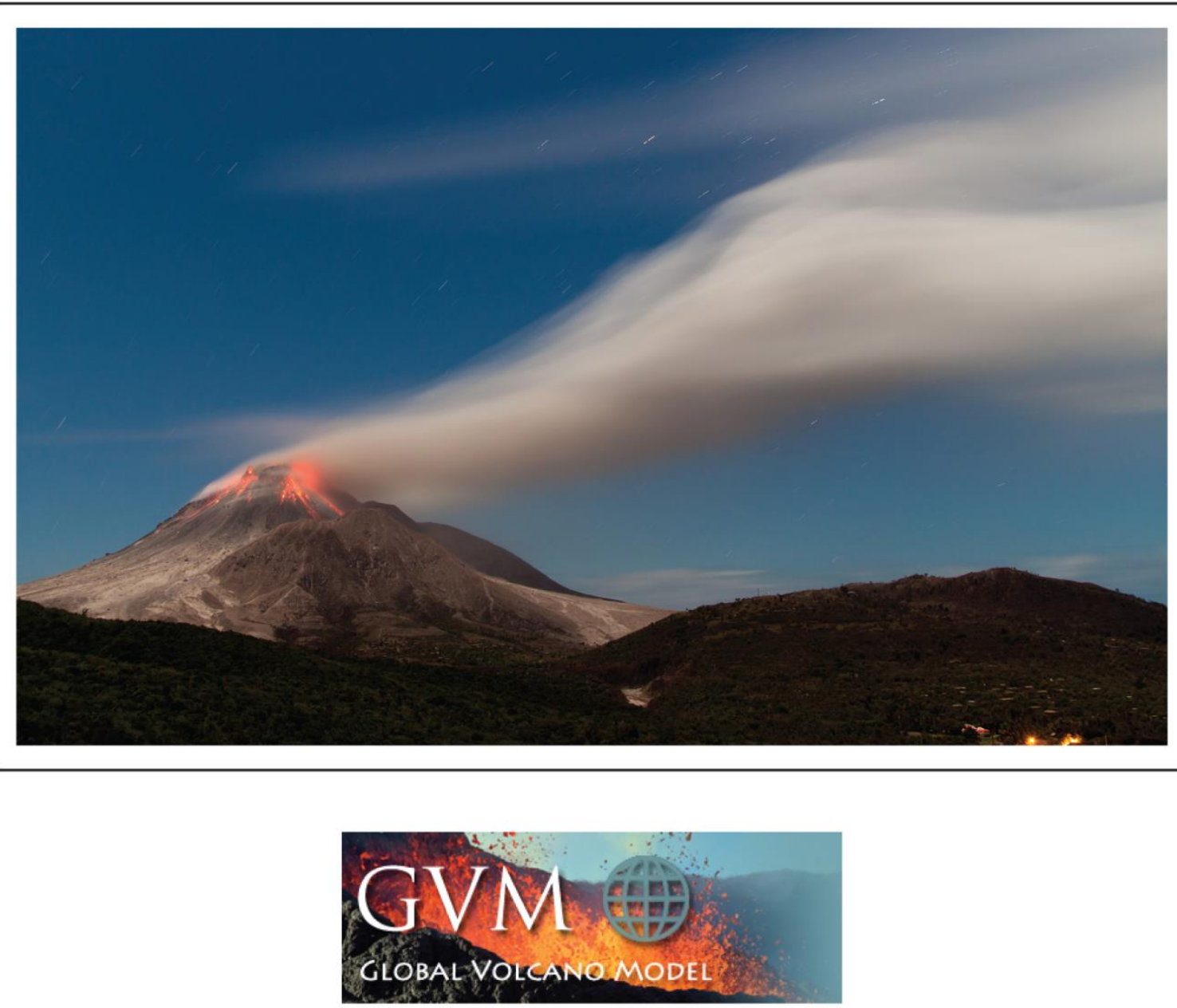

\section{- IAVCEI}

December 2014 
1. The Global Volcano Model (GVM; http://globalvolcanomodel.org/) was launched in 2011 and has grown to include 31 partner institutes collaborating from across the globe representing scientists from disciplines including volcanology, engineering and social science as well as private sector institutions. GVM is an international collaborative platform to integrate information on volcanoes from the perspective of forecasting, hazard assessment and risk mapping. The network aims to provide open access systematic evidence, data and analysis of volcanic hazards and risk on global and regional scales, and to support Volcano Observatories at a local scale.

2. The International Association of Volcanology and Chemistry of the Earth's Interior (IAVCEI; http://www.iavcei.org/) is an association of the International Union of Geodesy and Geophysics (IUGG). IAVCEI is the international association for volcanology with about 2000 members. The Association represents the primary international focus for: (1) research in volcanology, (2) efforts to mitigate volcanic disasters, and (3) research into closely related disciplines. There are 22 topic focussed Commissions of IAVCEI covering all aspects of volcanology, including hazards and risk.

\section{Contributors:}

Prepared by: Jenkins, S.F. ${ }^{1}$, Wilson, T.M. ${ }^{2,3}$, Magill, C.R. ${ }^{4}$, Miller, V. ${ }^{5}$, Stewart, C. ${ }^{3,6}$

\section{Content and Case Study}

contributors: Marzocchi, W. ${ }^{9}$; Boulton, M. ${ }^{1}$.

Reviewed by: Blong, R. ${ }^{7}$, Bonadonna, C. $^{8}$ and Costa, A. ${ }^{9}$

Institutions: ${ }^{1}$ University of Bristol, UK; ${ }^{2}$ University of Canterbury, New Zealand; ${ }^{3}$ New Zealand Natural Hazards Platform; ${ }^{4}$ Risk Frontiers, Macquarie University, Australia; ${ }^{5}$ Geoscience Australia; ${ }^{6}$ Joint Centre for Disaster Research, GNS Science/Massey University, Wellington, New Zealand; ${ }^{7}$ Aon Benfield Asia-Pacific; ${ }^{8}$ Université de Genève, Switzerland; ${ }^{9}$ Istituto Nazionale di Geofisica e Vulcanologia, Italy.

\section{Acknowledgements}

We are indebted to Russell Blong, Costanza Bonadonna and Antonio Costa, who offered insightful and detailed comments and reviews that greatly helped in developing this technical background paper.

The global ash fall hazard assessment (Section 3.1) was carried out in collaboration with co-authors John McAneney and Russell Blong and the input of Stuart Mead; the local ash fall hazard assessment (Section 3.2) benefits from the collaboration of co-authors Jacopo Selva and Laura Sandri, and invaluable discussions with Antonio Costa, Giovanni Macedonio and Roberto Tonini. The pilot volcanic ash fall hazard study for use in the CAPRA risk model (boxed text: Section 6) was undertaken with the collaboration of co-authors Adele Bear-Crozier, Vanessa Newey, Nick Horspool and Rikki Weber. This technical paper also benefitted from the support of Katharine Haynes and Claire Horwell for the social and health aspects of ash falls, respectively.

The authors would like to thank separate funding sources that have allowed them to contribute to this effort: The AXA Research Fund and VOLDIES ERC contract 228064 (SFJ), the New Zealand MBIE Natural Hazard Research Platform Subcontract C05X0804 (TW, CS) and Department of Foreign Affairs and Trade funding as part of the Australian Aid program (VM). This work was carried out under the auspices of the Global Volcano Model (GVM) and the International Association of Volcanology and Chemistry of the Earth's Interior (IAVCEI). The GVM Volcanic ash hazard working group and the IAVCEI Commission on Tephra hazard modelling supported the development of this technical paper. 
This is Section III of IV of the GVM/IAVCEI contribution to the UN ISDR GAR-15.

Suggested citation: Jenkins, S.F., Wilson, T.M., Magill, C.R., Miller, V., Stewart, C., Marzocchi, W. and Boulton, M., 2015. Volcanic ash fall hazard and risk: Technical Background Paper for the UNISDR 2015 Global Assessment Report on Disaster Risk Reduction. Global Volcano Model and IAVCEI. www.preventionweb.net/english/hyogo/gar

Cover image: The incandescent lava dome at the summit of Soufrière Hills Volcano, Montserrat. Photograph by Paul Cole. 


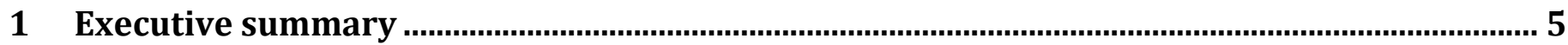

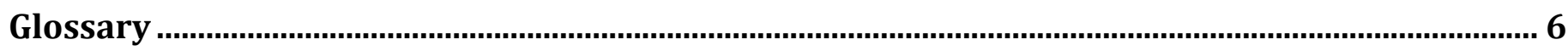

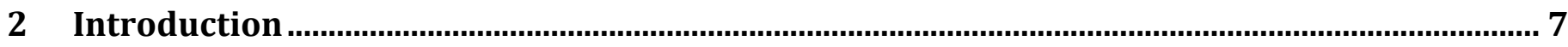

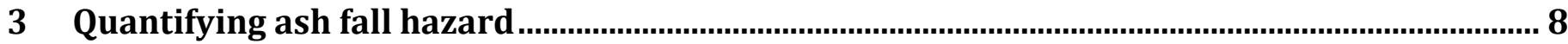

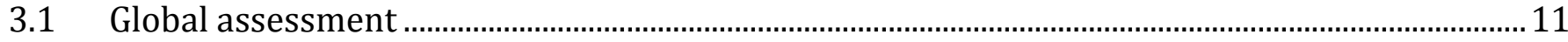

3.1.1 Methodology

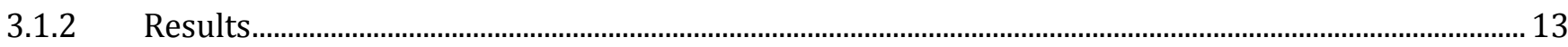

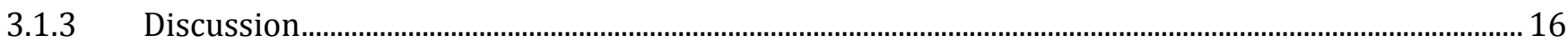

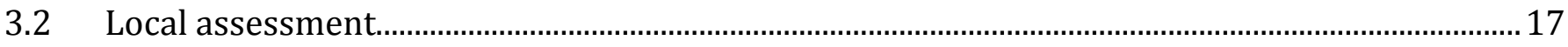

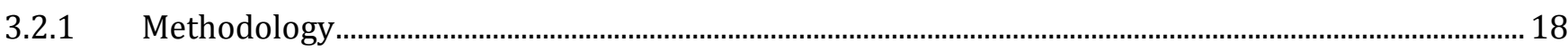

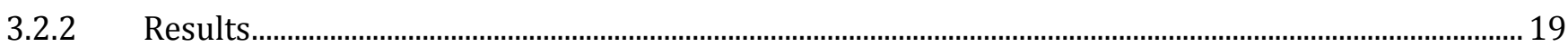

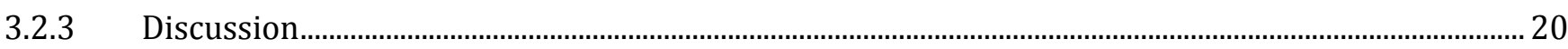

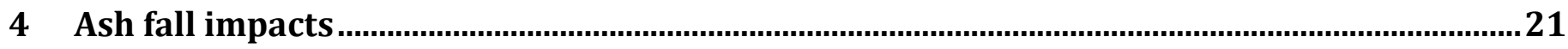

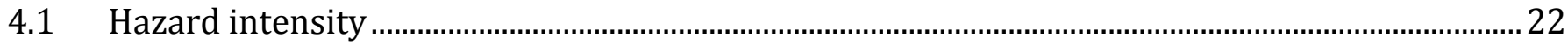

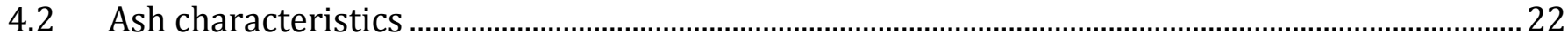

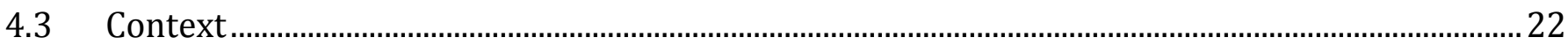

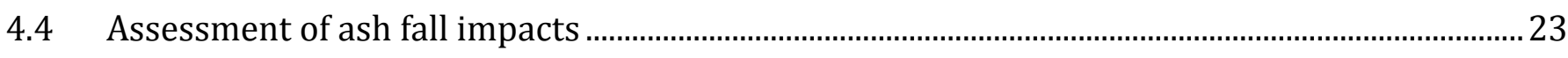

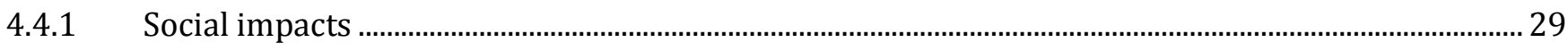

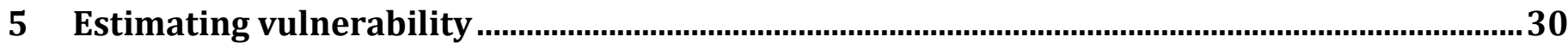

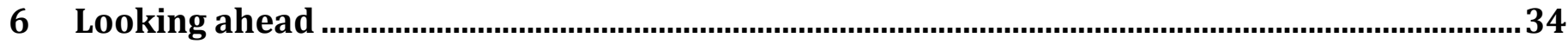

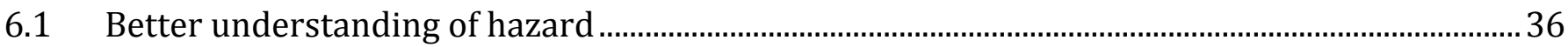

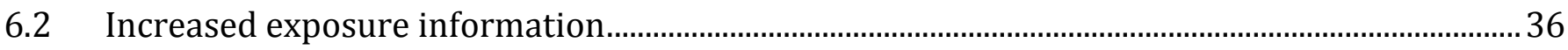

6.3 Improved understanding of impacts and associated vulnerability............................................... 36

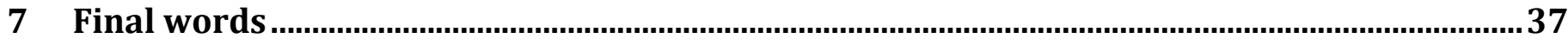

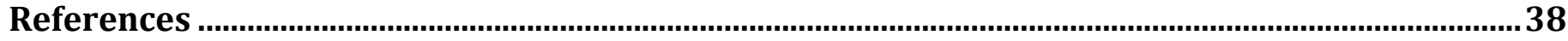




\title{
Volcanic ash fall hazard and risk
}

\author{
UNISDR 2015 Global Assessment Report on Disaster Risk Reduction Technical Background Paper
}

Susanna Jenkins 1, Thomas Wilson 2,3, Christina Magill 4, Victoria Miller 5, Carol Stewart 6,3, Warner Marzocchi ${ }^{7}$, Mike Boulton ${ }^{1}$.

${ }^{1}$ University of Bristol, UK; ${ }^{2}$ University of Canterbury, New Zealand; ${ }^{3}$ New Zealand Natural Hazards Research Platform; 4 Macquarie University, Australia; ${ }^{5}$ Geoscience Australia; ${ }^{6}$ Joint Centre for Disaster Research, GNS Science/Massey University, Wellington, New Zealand; ${ }^{7}$ Istituto Nazionale di Geofisica e Vulcanologia, Italy.

\section{Executive summary}

All explosive volcanic eruptions generate volcanic ash, fragments of rock that are produced when magma or vent material is explosively disintegrated. Volcanic ash is then convected upwards within the eruption column and carried downwind, falling out of suspension and potentially affecting communities across hundreds, or even thousands, of square kilometres. Ash is the most frequent, and often widespread, volcanic hazard and is produced by all explosive volcanic eruptions. Although ash falls rarely endanger human life directly, threats to public health and disruption to critical infrastructure services, aviation and primary production can lead to potentially substantial societal impacts and costs, even at thicknesses of only a few millimetres. Communities exposed to any magnitude of ash fall commonly report anxiety about the health impacts of inhaling or ingesting ash (as well as impacts to animals and property damage), which may lead to temporary socio-economic disruption (e.g. evacuation, school and business closures, cancellations). The impacts of any ash fall can therefore be experienced across large areas and can also be long-lived, both because eruptions can last weeks, months or even years and because ash may be remobilised and re-deposited by wind, traffic or human activities.

Given the potentially large geographic dispersal of volcanic ash, and the substantial impacts that even thin (a few $\mathrm{mm}$ in thickness) deposits can have for society, this technical background paper elaborates upon the ash component of the volcanic contribution to the UNISDR 2015 Global Assessment Report on Disaster Risk Reduction. We focus on the hazard and associated impacts of ash falls; however, the areas affected by volcanic ash are potentially much larger than those affected by ash falling to the ground, as fine particles can remain aloft for extended periods of time. For example, large portions of European airspace were closed for up to five weeks during the eruption of Eyjafjallajökull, Iceland, in 2010 because of airborne ash (with negligible associated ash falls outside of Iceland). The distance and area over which volcanic ash is dispersed is strongly controlled by wind conditions with distance and altitude from the vent, but also by the size, shape and density of the ash particles, and the style and magnitude of the eruption. These factors mean that ash falls are typically deposited in the direction of prevailing winds during the eruption and thin with distance. Forecasting ash dispersion and the deposition 'footprint' is typically achieved through numerical simulation.

In this technical background paper, we discuss volcanic ash fall hazard modelling that has been implemented at the global and local (Neapolitan area, Italy) scales (Section 3). These models are probabilistic, i.e. they account for uncertainty in the input parameters to produce a large number of possible outcomes. Outputs are in the form of hazard maps and curves that show the probabilities associated with exceeding key hazard thresholds at given locations. As with any natural hazard, these results are subject to uncertainty and the local case study describes how ongoing research is working to better quantify this uncertainty through Bayesian methods and models. Further to the ash fall hazard assessments, we discuss the key components required to carry these hazard estimates forward to risk: namely identification of likely impacts and the response (vulnerability) of key sectors of society to ash fall 
impact. The varied characteristics of volcanic ash, e.g. deposit thickness and density, particle size and surface composition, the context, e.g. timing and duration of ash fall, and resilience of exposed people and assets can all influence the type and magnitude of impacts that may occur. We draw from data collected during and following past eruptions and experimental and theoretical studies to highlight likely impacts for key sectors of society, such as health, infrastructure and the economy (Section 4). In many parts of the world, the failure, disruption or reduced functionality of infrastructure or societal activities, e.g. ability to work or go to school, is likely to have a larger impact on livelihoods and the local economy than direct damage to buildings. Broad relationships between ash thickness (assuming a fixed deposit density) and key levels of damage is also outlined (Section 5); however, vulnerability estimates are typically the weakest part of a risk model and detailed local studies of exposed assets and their vulnerability should ideally be carried out before a detailed risk assessment is undertaken.

Greater knowledge of ash fall hazard and associated impacts supports mitigation actions, crisis planning and emergency management activities, and is an essential step towards building resilience for individuals and communities. This technical background paper concludes with a discussion on where some of the important advances in ash fall hazard and risk assessment may be achieved, providing a roadmap for future research objectives.

\section{Glossary}

Tephra: Fragments of rock, regardless of size, that become airborne during a volcanic eruption.

Lapilli: Fragments of rock, between 2 and $64 \mathrm{~mm}$ in diameter, produced explosively during a volcanic eruption.

Volcanic ash: Tephra less than $2 \mathrm{~mm}$ in diameter, produced explosively during a volcanic eruption.

Ash (tephra) fall: Volcanic ash and lapilli dispersed by winds away from the volcano, falling out of suspension to form a deposit. Tephra falls are commonly referred to colloquially as ash falls.

Hazard: Potential threat arising from the physical phenomenon.

Hazard intensity: A parameter describing the severity of a hazard at a location, e.g. ash fall thickness.

Exposure: Societal assets (e.g. people, property, infrastructure networks) present in hazard zones that are thereby subject to potential losses.

Vulnerability: The degree to which characteristics and the circumstances of an individual, community, system, network or asset, and any interdependencies, makes it susceptible to the damaging effects of a hazard.

Impact: Function of the hazard and vulnerability on the exposed asset.

Risk: Function of both the characteristics of the hazardous event and the consequences for the exposed assets.

Resilience: The ability of a system, community or society exposed to hazards to resist, absorb, accommodate to and recover from the effects of a hazard in a timely and efficient manner, including through the preservation and restoration of its essential basic structures and functions. 


\section{Introduction}

Volcanic eruptions can produce a number of hazards that vary widely in their spatial distribution and in the impacts they can have for society. Localised phenomena, such as pyroclastic density currents and lahars, are the most destructive and dangerous (Auker et al., 2013); however, the most frequent, and often widespread, volcanic hazard is tephra, occurring in more than $90 \%$ of all eruptions (Newhall and Hoblitt, 2002). Tephra comprises fragments of rock produced when magma or vent material is explosively disintegrated during an eruption. Larger tephra ('blocks' or 'bombs') follow ballistic trajectories and pose a local threat (usually $<5 \mathrm{~km}$ ). Smaller diameter tephra (Figure 1) comprising lapilli ( 2 to $64 \mathrm{~mm}$ ) and ash $(<2 \mathrm{~mm}$ ) - are convected upwards within the eruption column or convective plume and dispersed away from the volcano by winds or buoyancy forces. Ash particles can be carried hundreds or even thousands of kilometres away from source falling out of suspension over large multi-national areas to form 'ash falls'. For example, the 1991 eruption of Hudson volcano in Chile covered an estimated 150,000 $\mathrm{km}^{2}$ of land with ash, most notably in Argentina (Scasso et al., 1994). Ash falls are the volcanic hazard with the greatest potential to directly or indirectly affect the largest number of people worldwide (Simkin et al., 2001; Witham, 2005).
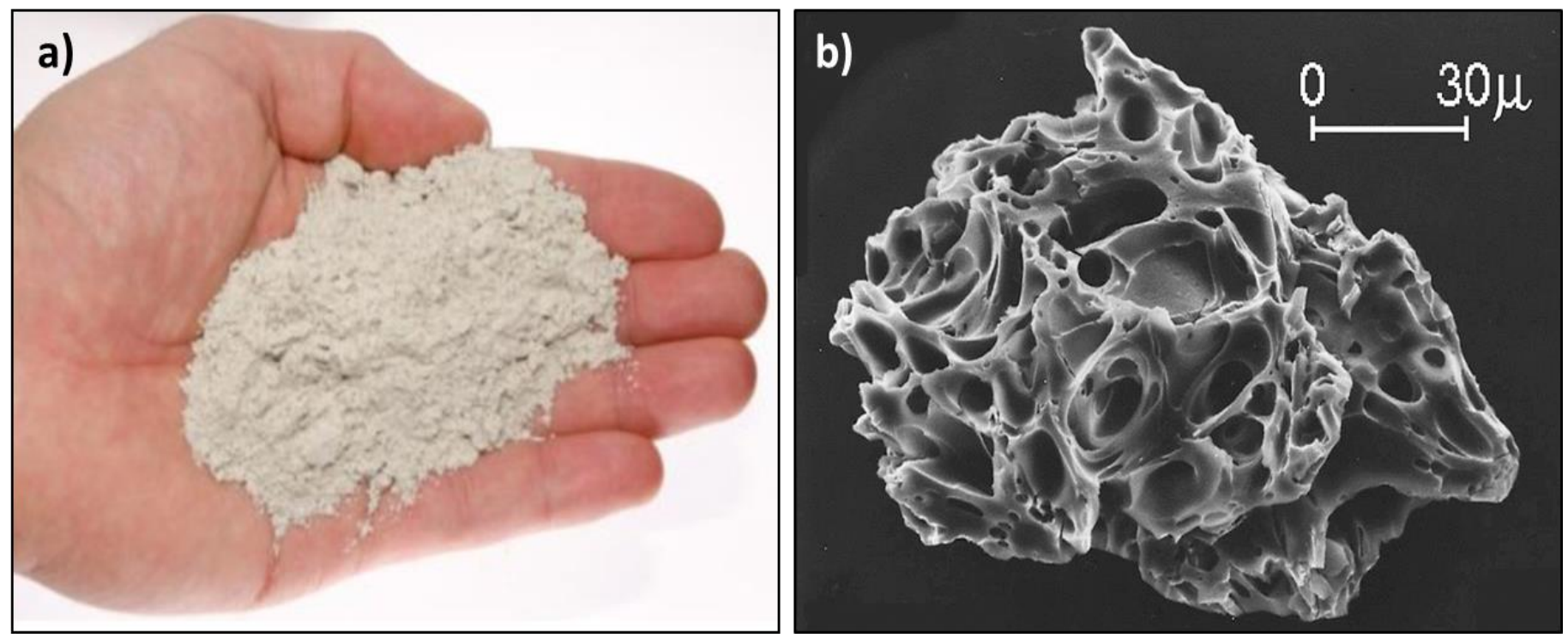

Figure 1: a) Rhyolitic ash produced by the VEI 4 eruption of Chaitén volcano, Chile, in 2008 (median particle size: 0.02 $\mathrm{mm}$ ); b) Scanning electron microscope image of an ash particle from the eruption of Mount St Helens, USA, in 1980. Vesicles, formed as gas expanded within solidifying magma, are clearly visible and increase the particle surface area; typically, ash is highly abrasive because of its irregular shape and hardness. Photos: a) G. Wilson, University of Canterbury; b) A.M. Sarna-Wojcicki, USGS.

Ash falls usually do not endanger human life directly, except where very thick falls cause structural damage (e.g. roof collapse) or where casualties are indirectly sustained, for example during ash clean-up operations or in traffic accidents. However, ash falls can threaten public health, with the short-term health effects of ash exposure typically being irritation of the eyes and upper airways and exacerbation of pre-existing asthma. Ash falls can also disrupt critical infrastructure services (e.g. electricity and water supply, aviation and other transport routes), damage buildings, and damage or disrupt agricultural production and other economic activities (Wilson et al., 2012b). Even relatively thin ash falls of a few millimetres can cause significant societal impacts, through widespread damage, disruption and economic loss. Impacts can be long-lived, either because eruptions may be long-duration or because ash falls may be remobilised by wind, water, traffic or human activities.

This technical background paper elaborates upon ash fall hazard and risk as part of the volcanic contribution to the UNISDR Global Assessment Report 2015 on disaster risk reduction (Brown et al., 2014). We provide information on how the volcanological community is addressing three major components of ash fall risk assessment: 1) quantifying the hazard; 2) identifying likely impacts; and 3) estimating vulnerability for key sectors of society. Understanding the 
breadth and severity of hazard and risk for ash falls of different thicknesses and characteristics is key to reducing the potential impact on livelihoods and socio-economic activities during future events.

In this technical background paper, we focus on the hazard and associated impacts of ash falls; however, volcanic ash poses problems for society both while being dispersed in the atmosphere and on the ground once deposited. In general, areas affected by airborne ash are much larger than those affected by ash falls because fine particles can remain aloft for extended periods of time creating a hazard for aviation and health but not producing discernible ash falls. For example, the direct impacts of ash fall from the relatively small (VEI 4 on a logarithmic scale from 0 to $8^{1}$ ) volcanic eruption of Eyjafjallajökull, Iceland, in 2010 were limited to the farming communities of southern Iceland. By contrast, large portions of European airspace were closed for up to five weeks because of airborne volcanic ash (with negligible associated ash falls). This airspace closure caused major disruption to the aviation industry and affected the transport of goods worldwide (IATA, 2010). In terms of the potential for multiple casualties and large economic losses, interaction of volcanic ash with aircraft represents the most important hazard from airborne ash, although respiratory health impacts are also of concern. Airborne volcanic ash is an important societal hazard but beyond the scope of this paper; it is covered in some detail in the technical volcano report and associated case studies (Brown et al., 2014).

\section{Quantifying ash fall hazard}

The distance and area over which volcanic ash is dispersed is strongly controlled by wind direction and speed, and atmospheric conditions (e.g. the presence of water) with distance from the vent, which can vary hourly, daily and seasonally, and with altitude above the vent, affecting particles as they fall through the atmosphere. Winds at the surface are usually different in direction and speed than winds higher in the atmosphere and winds throughout the atmospheric column typically vary in strength and direction according to the time of year. Thus the height of the eruption column, and the time of year, strongly influence where ash is dispersed to. Figure 2 shows the distribution and speeds of winds with height above a selection of cities in active volcanic areas; generally, wind speeds increase and directions become more consistent with increasing height because of global circulation patterns. While wind conditions have a strong control on ash dispersal, dispersal is also affected by the size, shape and density (and therefore fall velocities) of the ash particles, and the eruption style and magnitude. Larger, heavier fragments are typically deposited closer to source and smaller, lighter fragments dispersed farther downwind. The resulting deposit accumulates in a radial pattern around the volcano only where wind is absent; more typically, it is dispersed in the direction of the prevailing winds throughout the eruption (Figure 3). As a general rule, deposit thickness and particle size distribution reduce with distance from the volcano: decreases that can be well fitted by a Weibull distribution (Bonadonna and Costa, 2012). Aggregation of particles can lead to secondary maxima in deposit thickness and particle sizes at varying distances from the volcano (Figure 3). Quantifying the hazard from future ash falls can therefore be problematic, in part because of data limitations that make eruption characteristics uncertain, but also because, given an eruption, the distribution of ash is then controlled by time and altitude-varying wind and weather conditions.

\footnotetext{
${ }^{1}$ Volcanic Explosivity Index (VEI) - An estimate of explosivity magnitude for volcanic eruptions. VEI ranges from 0 to 8 on a logarithmic scale so that, for example, a VEI 5 eruption has ten times the erupted volume of a VEI 4 eruption (Newhall and Self, 1982).
} 


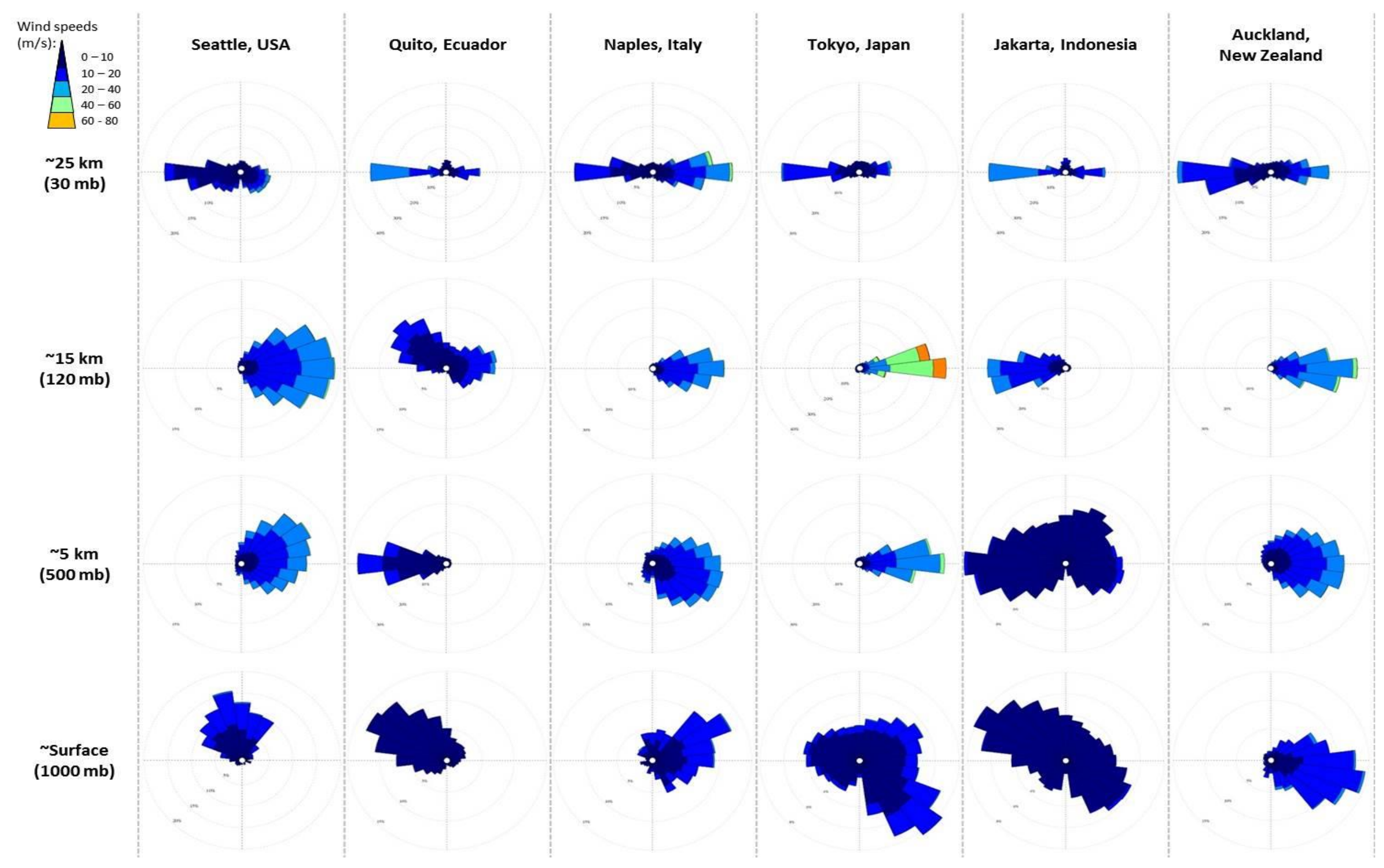

Figure 2: Wind roses with height above sea level for a selection of six cities in active volcanic areas. The wind roses show the frequency of winds, and the range of wind speeds, blowing towards particular directions during the period 2000 to 2009 (NCEP/NCAR 6 hourly reanalysis wind data). Standard compass directions are used with north at the top and east to the right of the wind roses. 


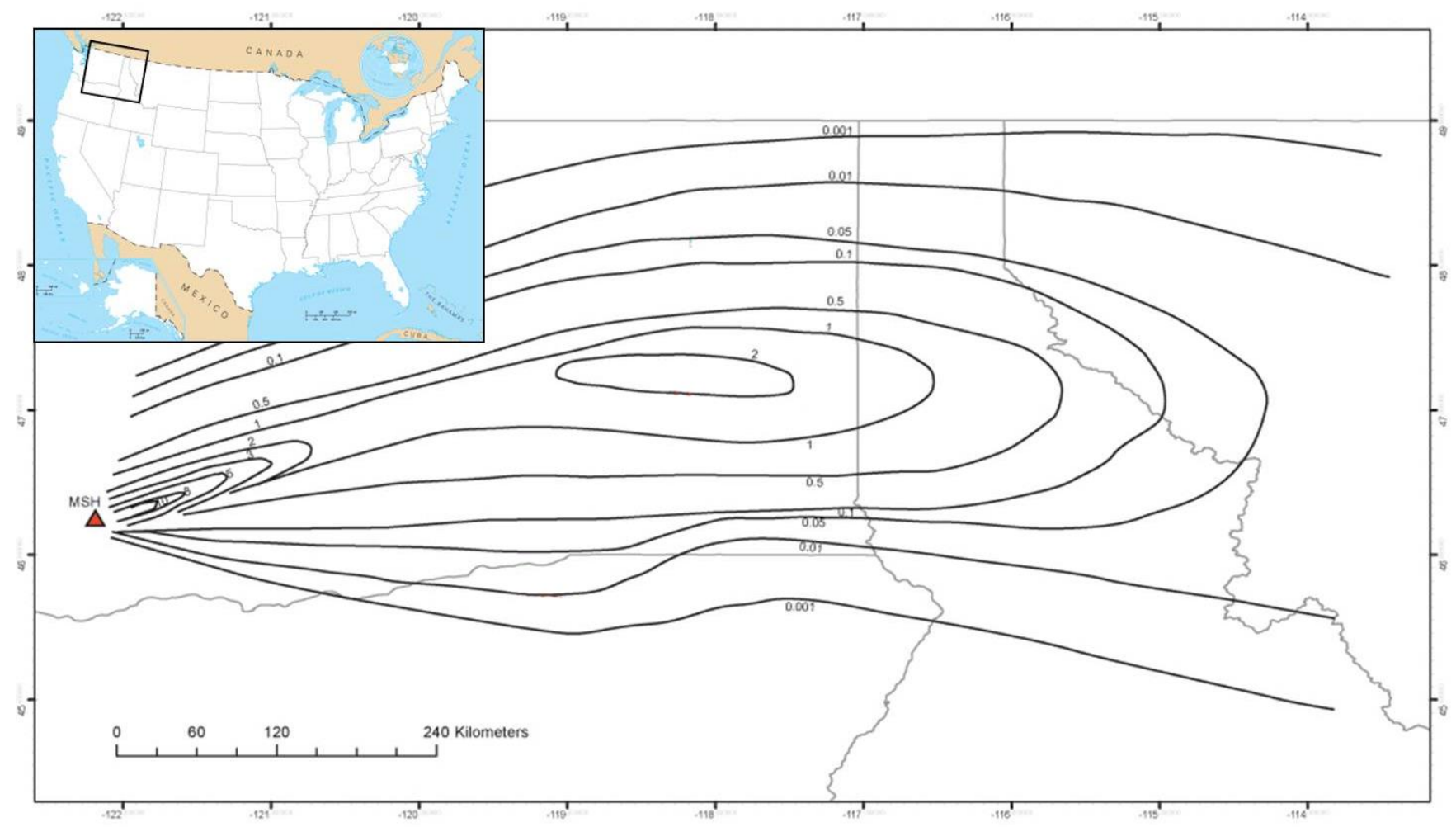

Figure 3: Isopachs (lines of equal ash fall thicknesses, here for $\mathrm{cm}$ of un-compacted ash) for ash fall produced during the 18 May 1980 eruption of Mount St Helens, USA (modified from Durant et al., 2009 and originally reproduced from Sarna-Wojcicki et al., 1981). The secondary maximum in deposit thickness approximately $400 \mathrm{~km}$ east of the volcano is likely attributed to aggregation of particles. Winds were predominantly westerly and ash was dispersed across multiple US states, affecting transport, health, agriculture and infrastructure (BGVN, 1980). Clearly, these impacts would have been markedly different had they been erupted into an easterly wind, with most ash dispersed to sea.

Quantitative ash fall hazard assessments have commonly been deterministic, in that they carry out single scenario simulations of historical or reference eruptions. Simulating historical scenarios can be useful for model calibration and for assessing what could happen if a well-known eruption took place in a modern day setting ('what if' scenarios). Reference scenarios build on this by considering that a particular volcano's eruptive history offers an indication of the range of future activity so that 'most likely' or 'maximum considered' eruption scenarios can be defined. These scenarios have typically been used for emergency management and response planning (e.g. Vesuvius, Italy: Zuccaro et al., 2008). However, as with many other natural hazard events, deterministic studies are increasingly being combined with, or subsumed within, probabilistic frameworks to allow understanding of the full range of plausible outcomes. Probabilistic methods are particularly important for determining volcanic ash fall hazard because the range of potential magnitudes, styles and external factors, such as wind conditions, may be large. A full hazard assessment should ideally account for the uncertainties associated with forecasting how much ash will be erupted and where it will be dispersed and deposited, and should be updateable as new information becomes available (e.g. Bonadonna, 2006).

Due to the complexities involved in forecasting ash dispersion and deposition, algorithms and numerical models are employed. Traditionally, numerical modelling of ash dispersal and deposition has been carried out for three purposes: 1) to better understand and quantify plume dynamics and particle sedimentation mechanisms, 2) to assess the hazard associated with ash fallout at ground level and 3) to assess the hazard from ash within the atmosphere. We focus here on the use of models and methods for ash fall hazard assessment. These approaches have been comprehensively reviewed by Bonadonna and Costa (2013) but, to summarise, there are three main approaches of differing complexity: 1) 1D theoretical thinning relationships (e.g. Pyle, 1989; Bonadonna and Costa, 2012), which typically utilise empirical data to estimate ash sedimentation with distance from the volcano; 2) analytical 1D or 2D models based on the advection-diffusion-sedimentation equation (e.g. Suzuki, 1983; Macedonio 
et al., 1988), which assume effective horizontal diffusion, negligible vertical components of wind velocity and diffusion and uniform atmospheric conditions with distance from the volcano; and 3) numerical 3D time-dependent models, based on Eulerian, Lagrangian or hybrid approaches to particle transport (e.g. Heffter and Stunder, 1993; Ryall and Maryon, 1998; Barsotti et al., 2008) that can be used to assess airborne ash concentrations. All ash dispersal models are subject to uncertainty because of inherent natural variability in volcanic and climatic systems and processes and because of an incomplete understanding of the processes by which ash from different eruption magnitudes and styles is dispersed. In theory, this latter uncertainty is being reduced, or at least better quantified, through continued model development and calibration, application of probabilistic approaches and sensitivity testing. The output from all ash dispersal models is a spatial appreciation of ash intensity (thickness, load or atmospheric concentration).

In the following sections, we present probabilistic ash fall hazard modelling approaches at the global and local scales, as a demonstration of the range of methods available for this type of analysis. Alternative methods are also available, as discussed above. When considering the appropriate model to use for ash hazard analysis, one must consider the purpose of the assessment, its end-users and assessment period, the required resolution, available data and any logistical constraints, such as computational resources or time. Careful consideration of the methodology is necessary to ensure that the results are valid and fit for purpose. For example, models at global or regional scales are typically only appropriate to long-term (years to decades) hazard estimation because of high-level data requirements and analyses that typically prohibit near real-time assessment. Locally applied models can incorporate timedependent knowledge such as monitoring data to allow short-term hazard estimation, i.e. hourly, daily or weekly, during times of unrest.

\subsection{Global assessment}

Few global studies of volcanic hazard or risk have been attempted: Yokoyama et al. (1984), Small and Naumann (2001) and Dilley et al. (2005) all undertook global volcanic hazard analyses but, for the only study in which volcanic hazard was defined spatially (Small and Naumann, 2001), a constant level of hazard was assumed within concentric circles of $200 \mathrm{~km}$ radii extending from the source volcano. These types of analyses, while providing valuable early estimations, were erroneous and misleading with respect to ash fall hazard because they did not account for the varying dispersion of ash due to time- and altitude-varying wind conditions and did not account for potentially different eruption magnitudes or styles from the volcano in question.

In an attempt to deal with these uncertainties, Jenkins et al. (2012a and 2012b) developed a quantitative framework for assessing ash fall hazard on a regional scale. This methodology employed stochastic simulation techniques, utilising statistical analyses of eruption frequencies and magnitudes, a numerical ash dispersal model and multidecadal time-series of wind conditions at each volcano in the Asia-Pacific Region. Typically, ash fall hazard assessments consider the hazard from a single volcano (e.g. Macedonio et al., 2008; Costa et al., 2009). However, such studies may not fully capture the ash fall hazard in volcanically active areas where one location may potentially be affected by ash falls from multiple volcanoes (e.g. modelling suggests that at least 55 volcanoes are capable of depositing ash in central Tokyo: Jenkins et al., 2012b). The approach suggested by Jenkins et al. (2012a) deliberately accumulates ash fall hazard on a cell-by-cell basis so that all volcanoes capable of impacting each cell are considered. For the UNISDR 2015 Global Assessment Report, and as part of the Global Volcano Model, we expanded the existing methodology of Jenkins et al. (2012a) to carry out a first global probabilistic ash fall hazard assessment.

\subsubsection{Methodology}

- Identifying volcanoes for analysis

Data regarding eruptive behaviour for volcanoes around the world were sourced from the Smithsonian Institution's newly revised 2013 Global Volcanism Program catalogue of Holocene (approximately the last 10,000 years) events (volcano.si.edu). To be considered in our analysis, volcanoes had to have exhibited at least one recorded eruption in 
the Holocene, and not be classified as submarine, hydrothermal, fumarolic or of unknown type, giving a total of 720 volcanoes (Figure 4).

\section{- Deriving unique eruption frequency-magnitude relationships}

A statistical analysis of the global eruption record was carried out to determine unique eruption frequencymagnitude relationships for each of the 720 volcanoes based upon the eruption history of each volcano and the averaged eruptive behaviour of analogous volcanoes globally, following the methodology of Jenkins et al. (2012a) (Appendix A). To determine which portion of a volcano's eruption record could be considered complete, and thus useful for data mining, step changes in the cumulative number of eruptions with time (representing completeness dates) were identified for different geographic regions and eruption magnitudes (results shown in Mead and Magill, 2014). While we calculate average recurrence intervals for all possible eruption magnitudes, we only simulate large magnitude eruptions ( $V E I \geq 4$ ) due to their potential for generating thicker and more widely dispersed ash falls. Ash falls from smaller magnitude eruptions (VEI $\leq 3$ ) will not extend as far from the source volcano or produce such large thicknesses because of the volume of ash produced and the column height to which it is erupted. However, they will occur more frequently: a VEI 3 eruption is around twice as likely as a VEI 4 eruption, but about an order of magnitude smaller (Newhall and Self, 1982).

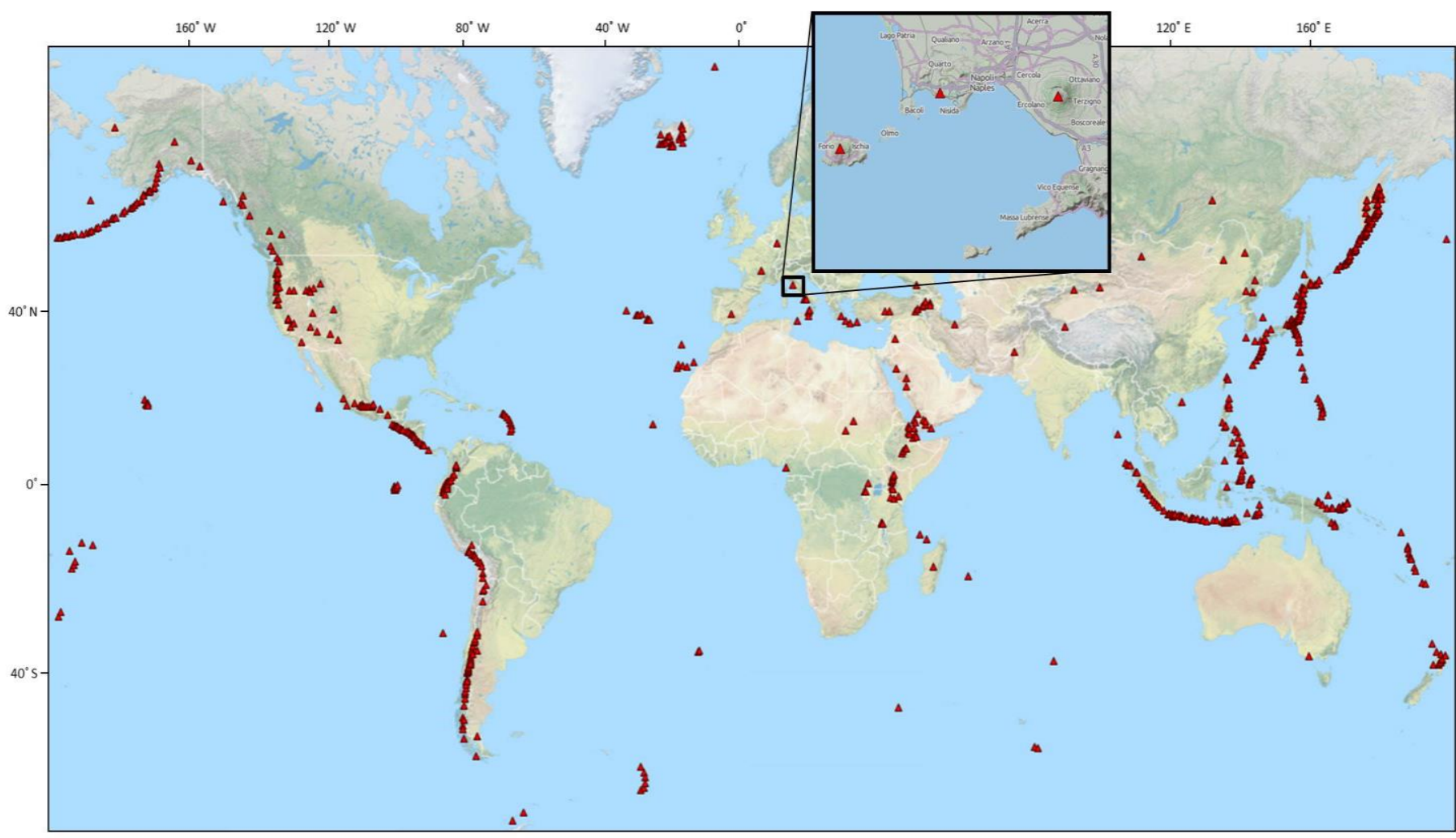

Figure 4: Map showing volcanoes considered in the global assessment of ash fall hazard ( $n=720)$. Local case study volcanoes (Section 3.2) are shown in the inset box. Base map provided by OpenStreetMap.

\section{- Ash dispersal modelling}

The ash dispersal model ASHFALL (Hurst, 1994) was used to simulate a large range (up to 19,200) of possible ash footprints for each volcano, on a $10 \times 10 \mathrm{~km}$ grid that extended $1000 \mathrm{~km}$ from the volcano in question. Analytical 2D models like ASHFALL are well suited to probabilistic assessments because a large number of simulations can be carried out efficiently using available computing resources. However, local use of these types of models should be limited to relatively small computational domains for which the assumption of uniform wind is likely to be valid (e.g. a few hundreds kms). Variations in possible erupted ash volume, column height, wind conditions and parameters, such as settling velocity (derived from particle size distribution and density), were accounted for by randomly sampling from predefined probability distributions (Table 1). The probability distributions dictated the magnitude and allowable range for each variable, and their relative likelihoods within this range. 
Table 1: ASHFALL model inputs, derivations, ranges and references used for the global ash hazard assessment. The horizontal diffusion coefficient and Suzuki constant were not sampled and remained constant for all simulations. For further details the reader is referred to Jenkins et al. (2012a).

\begin{tabular}{|c|c|c|c|c|}
\hline Input & Derivation & Min. & Max. & Source \\
\hline VEI & $\begin{array}{l}\text { An equal number of simulations }(n=4800) \\
\text { were carried out for each VEI class to } \\
\text { allow for possible variations in wind } \\
\text { conditions }\end{array}$ & VEI 4 & VEI 7 & \multirow[t]{2}{*}{ Newhall and Self, 1982} \\
\hline $\begin{array}{l}\text { Eruption } \\
\text { volume }\end{array}$ & $\begin{array}{l}\text { Sampled from a power law distribution } \\
\text { within the determined VEI classification }\end{array}$ & $\begin{array}{c}0.1 \mathrm{~km}^{3} \\
\text { (low VEI 4) }\end{array}$ & $\begin{array}{l}1000 \mathrm{~km}^{3} \\
\text { (high VEI 7) }\end{array}$ & \\
\hline $\begin{array}{c}\text { Column } \\
\text { height }(Z)\end{array}$ & $\begin{array}{l}\text { Related to eruption volume }(V) \text { by }^{2} \text { : } \\
\qquad Z=8.67 \log _{10}(V)+20.2\end{array}$ & $11.5 \mathrm{~km}$ & $46 \mathrm{~km}$ & $\begin{array}{l}\text { Carey and Sigurdsson, 1989; } \\
\text { Jenkins et al., } 2007\end{array}$ \\
\hline $\begin{array}{l}\text { Settling } \\
\text { velocities }\end{array}$ & $\begin{array}{c}\text { Means and standard deviations varied for } \\
\text { each simulation to give a truncated } \\
\text { lognormal distribution }\end{array}$ & $0.3 \mathrm{~m} / \mathrm{s}$ & $9.5 \mathrm{~m} / \mathrm{s}$ & $\begin{array}{l}\text { Walker, 1981; Woods and Bursik, } \\
\text { 1991; Sparks et al., } 1992\end{array}$ \\
\hline $\begin{array}{l}\text { Wind } \\
\text { conditions }\end{array}$ & \multicolumn{3}{|c|}{$\begin{array}{l}\text { Uniform sampling of wind speed and direction at } 35 \text { height levels from a } \\
40 \text { year ERA-Interim record closest to the volcano ( } 1.5 \text { degree grid). }\end{array}$} & $\begin{array}{l}\text { European Centre for Medium } \\
\text { range Weather Forecasting global } \\
\text { re-analysis project } \\
\text { (www.ecmwf.int) }\end{array}$ \\
\hline \multicolumn{2}{|r|}{ Horizontal diffusion coefficient } & \multicolumn{2}{|c|}{$6,000 \mathrm{~m}^{2} / \mathrm{s}$} & Hurst, 1994 \\
\hline & Suzuki constant & \multicolumn{2}{|c|}{5} & $\begin{array}{l}\text { Macedonio et al., 1988; Hurst, } \\
1994\end{array}$ \\
\hline
\end{tabular}

\subsubsection{Results}

For each modelled grid cell, the ash fall hazard was identified by considering all simulations from each volcano that impacts the grid cell and summing the corresponding annual eruption probabilities over all eruptions, potentially from a number of volcanoes. For each cell, the annual probability (or inversely the average recurrence interval) for ash thickness exceeding certain accumulation thresholds can then be calculated - for a given volcano, a selection or all volcanoes, and for different seasons or eruption magnitudes. Here we show the aggregated results (Figures 5, 6 and 7), incorporating the full range of possible eruption scenarios and environmental conditions. The influence of tectonic setting and prevailing wind conditions (e.g. predominantly to the east in the Americas) on the aggregated ash hazard is clear, with greater hazard being calculated along the major subduction zones where higher eruption frequencies and magnitudes may be expected. .

\footnotetext{
${ }^{2}$ This relationship is valid for the large eruptions simulated here (VEI $\geq 4$ ) for which duration is typically a few hours. For long-duration or smaller magnitude eruptions, a stronger empirical relationship exists between column height and mass eruption rate (Wilson and Walker, 1987)
} 


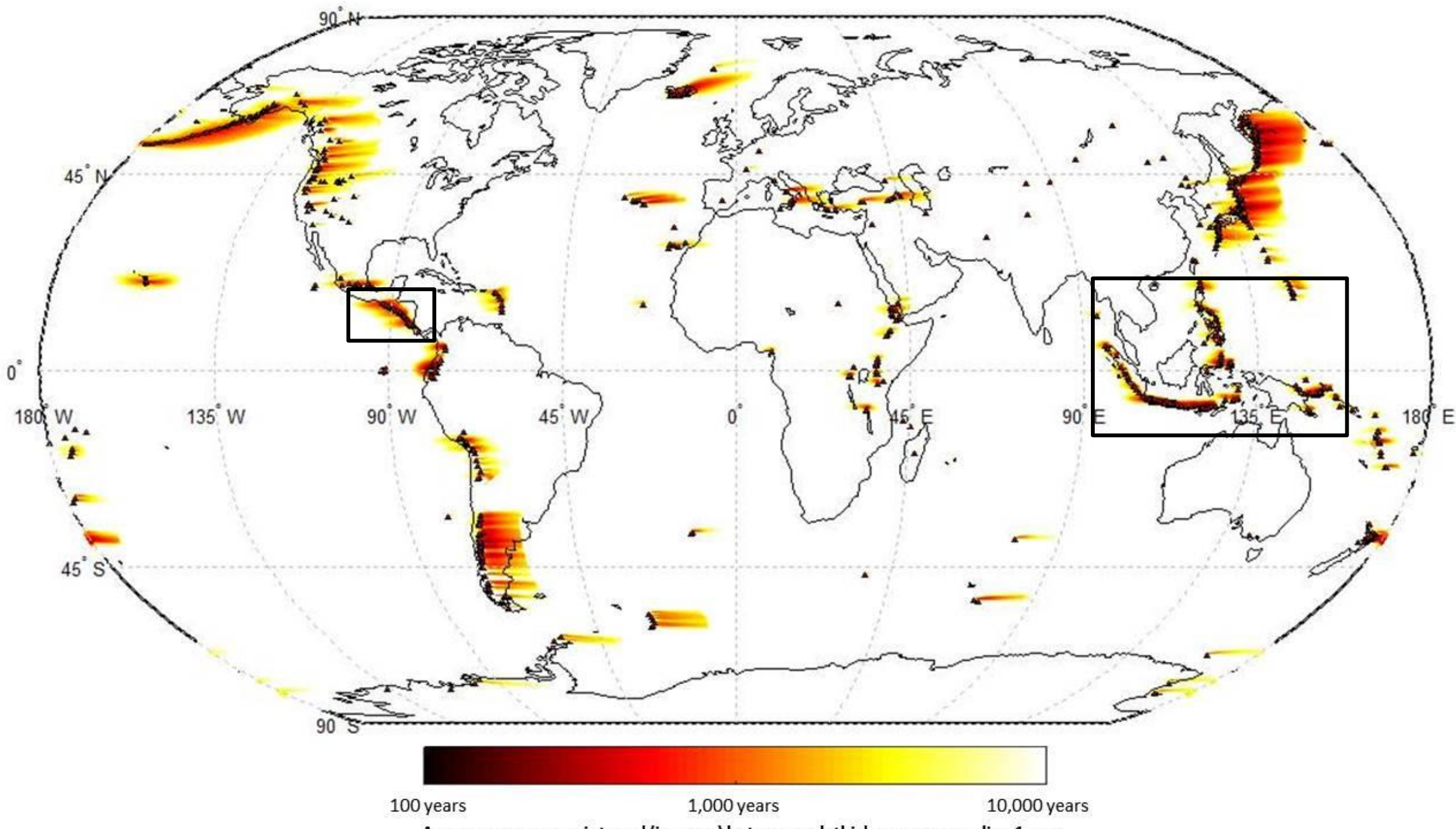

Average recurrence interval (in years) between ash thicknesses exceeding $1 \mathrm{~mm}$

Figure 5: Global map of probabilistic ash fall hazard, displayed here as the average recurrence interval between ash fall thicknesses exceeding 1 mm: a threshold that may cause concern for the aviation industry and critical infrastructure. Ash concentration in the atmosphere (and thus the cause of flight disruptions during the 2010 Eyjafjallajökull eruption in Iceland) are not output by $2 D$ modelling and so disruption can occur, and has occurred, in areas where ash fall thicknesses are significantly less than $1 \mathrm{~mm}$ (e.g. Folch and Sulpizio, 2010; Biass et al., 2014). Enlarged maps are shown for the inset boxes in Figure 6. 

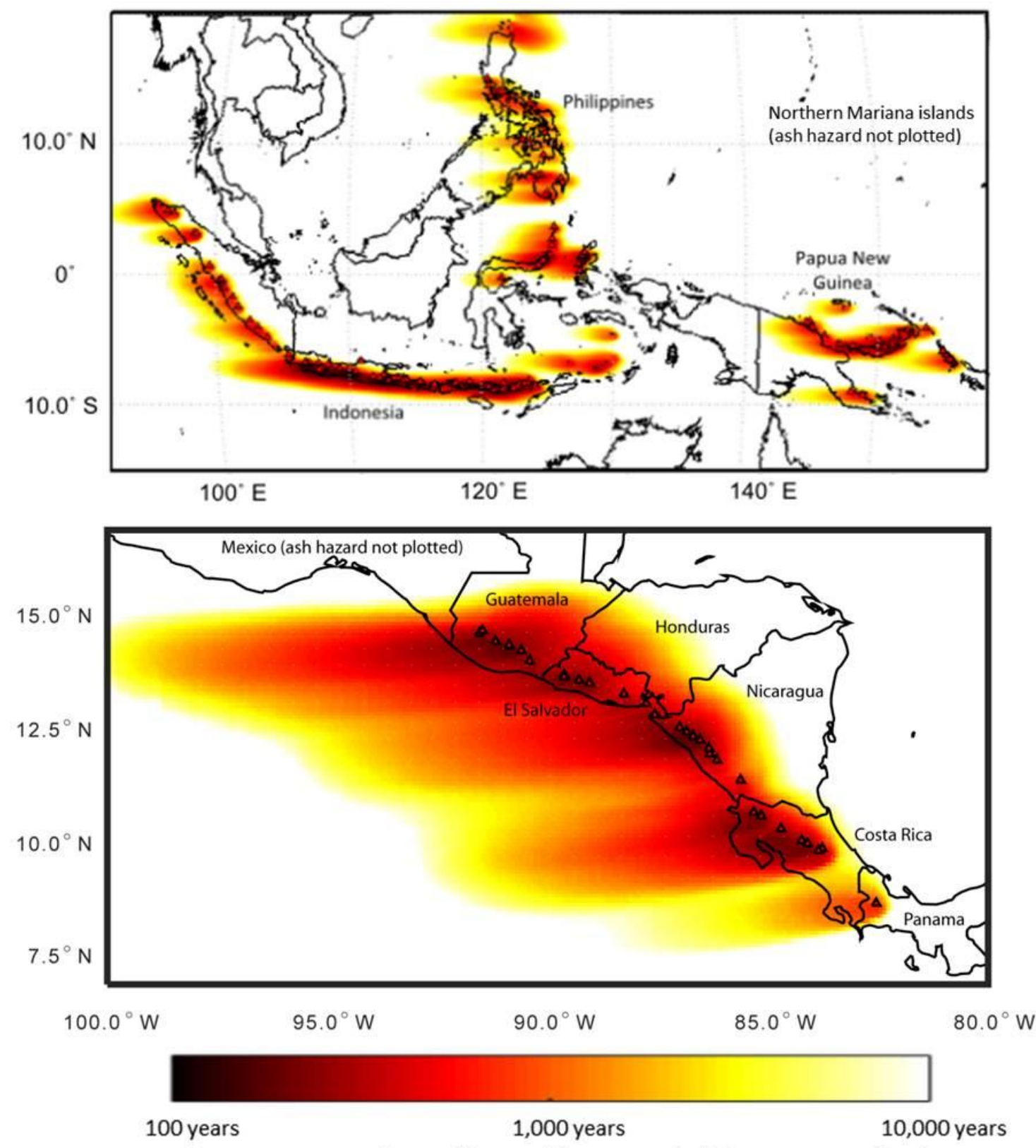

Average recurrence interval (in years) between ash thicknesses exceeding $1 \mathrm{~mm}$

Figure 6: Regional maps of probabilistic ash fall hazard, displayed here as the average recurrence interval between ash fall thicknesses exceeding $1 \mathrm{~mm}$. A few $\mathrm{mm}$ of ash can disrupt transport, power and water systems and, at the wrong time of year, can affect crop pollination and productivity.

The advantage of an aggregated multi-volcano probabilistic approach is that the ash fall hazard at any grid cell can be estimated for all ash fall thicknesses and all simulated average recurrence intervals, allowing a hazard curve to be built. Hazard curves compare hazard intensity (in this case thickness) to the expected annual probability of exceedance or average recurrence intervals and are useful for comparing the hazard at important locations, e.g. cities, airports or proposed infrastructure sites. They can act as fore-runners to more detailed local study, particularly by identifying which volcano or volcanoes may contribute most to the overall hazard (Figure 7). Tokyo, Manila and Jakarta are megacities of more than 10 million people located in volcanically active regions where ash falls of $10 \mathrm{~mm}$ or more may be expected at least every 1000 years. Within $1000 \mathrm{~km}$ of Tokyo, Jakarta and Manila, respectively, 57, 35 and 13 potentially active volcanoes have been identified. However, ash fall hazard in each city is not a direct function of volcano proximity and will be dictated by likely eruption frequencies, magnitudes and wind conditions. Figure 7 shows that Tokyo is estimated to have the highest relative ash fall hazard for thicknesses exceeding $1 \mathrm{~mm}$, which may be expected given the large number of surrounding volcanoes. Despite having the lowest number of surrounding volcanoes of the three cities, the frequency of ash falls in Manila is comparable to that of Jakarta. This is a result of the ash fall hazard in Manila being dominated by few local sources upwind from the 
city, which are capable of producing relatively large thicknesses in Manila. By contrast, ash fall hazard in Jakarta is expected to be influenced more by numerous distal sources resulting in a greater number of thinner and less frequent falls (hence the more shallow hazard curve). Readers are reminded that these values represent a minimum hazard as small magnitude and long-quiescent volcanoes are not considered.

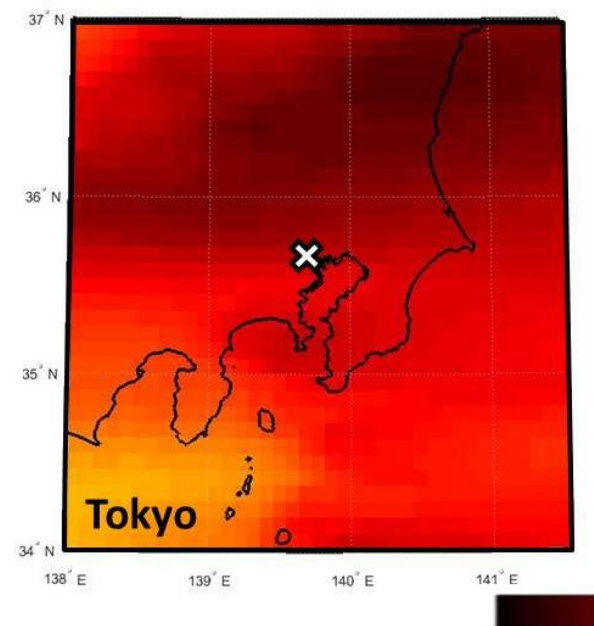

100 years

1,000 years

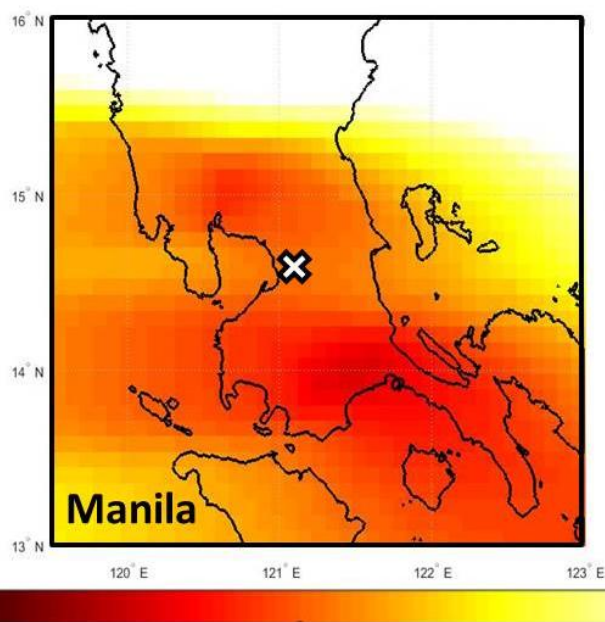

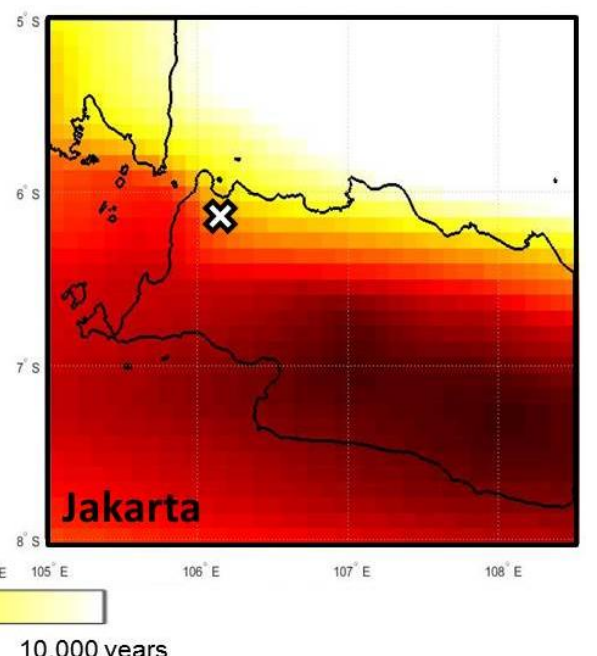

10,000 years
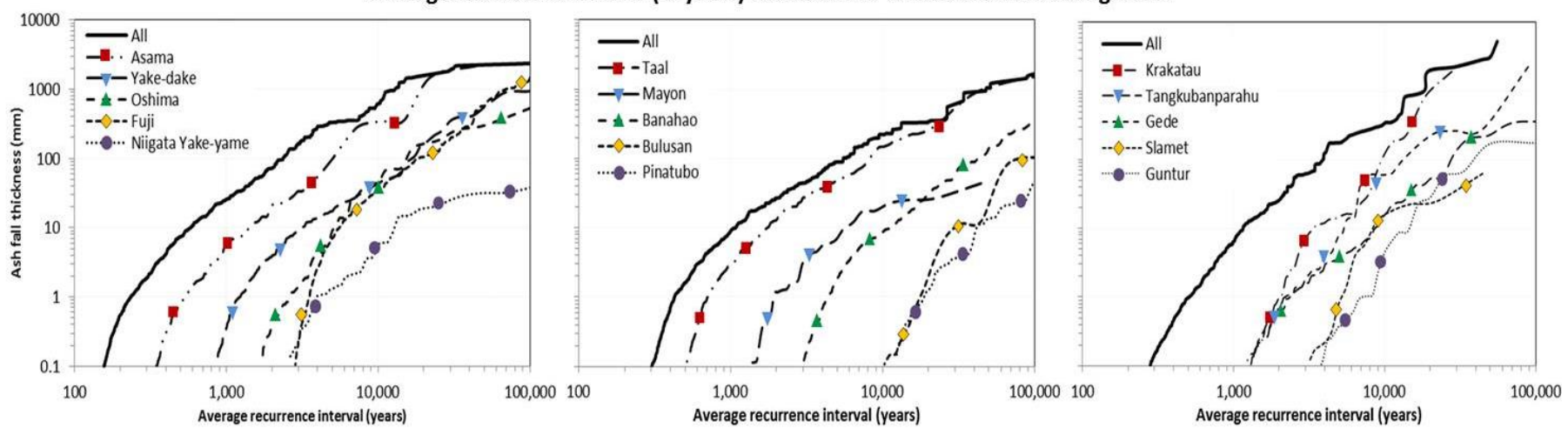

Figure 7: Ash fall hazard maps (average recurrence intervals for thicknesses of $1 \mathrm{~mm}$ or more) and curves across a) Tokyo, Japan, b) Manila, Philippines, and c) Jakarta, Indonesia. The cross marks the centre of each city. Ash hazard curves show the average recurrence intervals between exceeding the range of ash thicknesses, aggregated across all volcanoes (solid left most curve) and disaggregated to show hazard by volcano (curves to right). These draw from the global hazard modelling and are therefore useful for highlighting the relative hazard from large magnitude eruptions. They should not be used in place of more detailed local studies and represent a minimum hazard as discussed in the text.

\subsubsection{Discussion}

A global probabilistic ash fall hazard assessment has been produced for the first time using numerical simulation. Probabilistic methods were applied to capture the range of possible eruption scenarios (VEI $\geq 4$ ) at each active volcano around the world $(n=720)$ and, critically, to incorporate likely variability in wind speeds and directions, with altitude at each volcano (12.9 million scenarios total globally). As with any numerical representation of a complex and variable natural phenomenon, there are limitations to this approach. These are outlined in Jenkins et al. (2012a), but include:

- Uncertainty in estimating the completeness of available eruption data affects the calculation of eruption probabilities, particularly in areas where breakpoints between complete and incomplete subsets of data are difficult to identify. The uncertainty in identifying breakpoints has been reduced in this study by applying the statistical techniques shown in Mead and Magill (2014).

- Volcanoes that have no recorded eruptions in the Holocene (approximately the last 10,000 years) - either because there have been no eruptions, few or no geological studies or observations at the volcano or inaccurate 
dating of the deposits - have not been included in our assessment. The probability-weighted contribution to the hazard from volcanoes with long quiescent intervals in the order of 10,000 years or more that have not erupted in the Holocene will be minimal. However, calculated eruption frequencies at volcanoes with inadequate eruption records are subject to greater uncertainty until further studies are carried out. For example, prior to the VEI 4 eruption of Chaitén volcano in Chile in 2008, the eruption record contained one previous eruption, approximately 9,400 years earlier. Geological investigations in the years since 2008 have identified a further two large magnitude eruptions approximately 5100 and 370 years before present.

- By drawing data from volcano analogues to supplement eruption frequency-magnitude relationships, we average behaviour across multiple volcanoes. A more detailed volcano-by-volcano assessment is not possible for many areas because few geological or historical records exist.

- To limit data and computing requirements, and thus allow simulation of a large number of eruption scenarios, our model assumes wind fields remain uniform with time and distance from the source volcano: this means that in areas with markedly variable wind fields model results are potentially less reliable with distance.

- Only large magnitude explosive eruptions (VEI 4 to 7) are considered, with ash fall simulated to a maximum distance of $1000 \mathrm{~km}$ from the volcano due to the rarity and low intensity of ash falls beyond that extent. Therefore, in proximal areas, the ash hazard contribution from smaller explosive eruptions is missing and in very distal areas $(>1000 \mathrm{~km})$ the contribution from very large explosive eruptions is not considered. VEI 8 eruptions are known to have occurred in the past, e.g. at Yellowstone volcano, USA, 640,000 years ago; however, none have been produced in the Holocene and are thus absent from this assessment.

The use of this approach is justified here in providing a broad, state-of-the-art assessment of ash fall hazard for all active terrestrial volcanoes across the globe, allowing us to identify areas of higher, and lower, hazard and volcanoes and regions which may benefit from further, more detailed, study. A comprehensive volcanic hazard assessment must also consider the spectrum of additional volcanic hazards, such as pyroclastic density currents, lahars and lava flows.

\subsection{Local assessment}

The Neapolitan area in Italy represents one of the highest volcanic risk areas in the world, both because of the presence of three potentially explosive and active volcanoes (Vesuvius, Campi Flegrei and Ischia), and because of the extremely high exposure (over a million people located in a very large and important metropolitan area). Even though pyroclastic density currents are likely to be more destructive, ash falls pose a serious threat to the area because they impact over much larger areas and may cause major disruption to the European economy (Folch and Sulpizio, 2010).

Previous studies for the Neapolitan area have combined field data of ash fall deposits and numerical simulations of ash dispersal (often considering tens of thousands of wind profiles to account for wind variability) to assess ash fall hazard from Neapolitan volcanoes (Figure 8) (e.g. Barberi et al., 1990; Cioni et al. 2003; Macedonio et al. 2008; Costa et al., 2009). However, these studies have produced conditional ash load probability maps (i.e. not accounting for the probability of eruption) for a specific scenario (e.g. fixing magnitude, intensity and vent position) or for a few reference scenarios at Mount Vesuvius and Campi Flegrei. This could be considered a semi-probabilistic approach because variability in wind conditions is accounted for, but variability in eruption style, frequency, magnitude and location, and their associated probabilities of occurrence, is not. These approaches are still largely used in volcanology, but have severe limitations in representing the real volcanic hazard. Selva et al. (2010) and Marzocchi et al. (2010) have attempted to overcome some of these limitations by building on the Campi Flegrei ash fall hazard assessment of Costa et al. (2009). In particular, this work has developed the Bayesian Event Tree Volcanic Hazard tool (BET_VH: Marzocchi et al., 2010; vhub.org/resources/betvh), which accounts for the most important sources of uncertainty and natural variability in eruptive processes, statistically combining the contribution to the final probabilistic volcanic hazard analysis from all possible scenarios, making use of the law of total probability. 


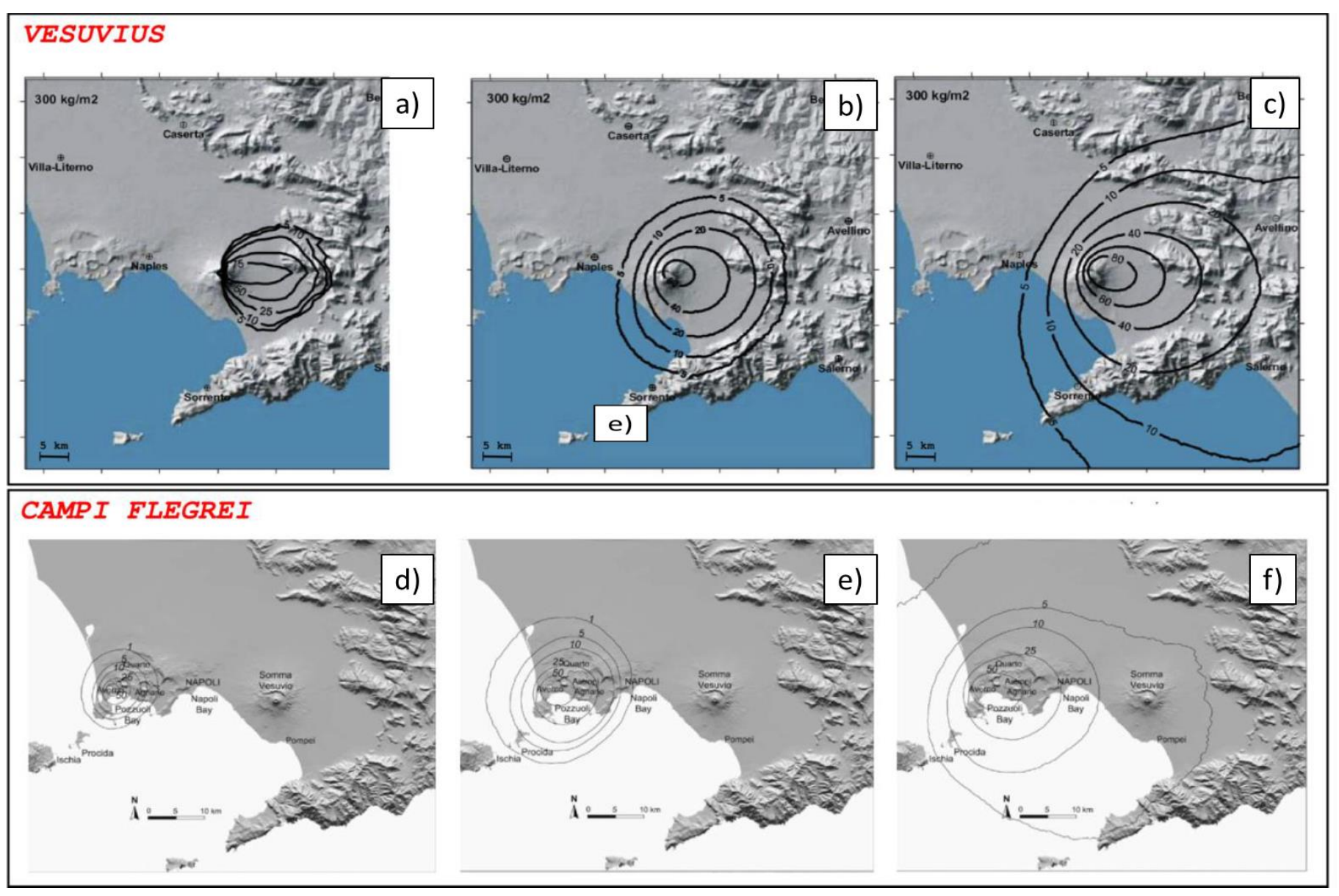

Figure 8: Maps showing the probability of ash fall loads exceeding $300 \mathrm{~kg} / \mathrm{m}^{2}$ given the occurrence of an eruption of size Violent Strombolian (a), Subplinian (b) and Plinian (c) at Vesuvius (Macedonio et al., 2008), and of size low (d), medium (e) and high (f) explosive, from the eastern vent (Averno-Monte Nuovo) at Campi Flegrei (Costa et al., 2009). A loading of $300 \mathrm{~kg} / \mathrm{m}^{2}$ is expected to result in significant (>80\%) of weak flat wooden, reinforced concrete and steel roofs (Costa et al., 2009; Zuccaro et al., 2008).

\subsubsection{Methodology}

BET-VH is an open source tool, based on Bayesian inference modelling, that properly accounts for the aleatoric (intrinsic natural variability) and epistemic (linked to our limited knowledge of the eruptive process) uncertainties, propagating these through to a probabilistic ash hazard assessment. This method, including accounting for the related uncertainties, can be described by a probability density function denoted as $[\theta]$. The analysis is based on an Event Tree (see Figure 9), and all uncertainties are assessed at each level, namely on the eruption occurrence ( $\left[\theta_{1-2-}\right.$ $\left.\left.{ }_{3}\right]\right)$, on vent position $\left(\left[\theta_{4}\right]\right)$, on the eruptive scale $\left(\left[\theta_{5}\right]\right)$, on the production of ash $\left(\left[\theta_{6}\right]\right)$ and on its transport, dispersal and deposition by the wind $\left(\theta_{7}\right]$ and $\left.\left[\theta_{8}\right]\right)$, according to the following equation (from Marzocchi et al., 2010):

$$
\left[\theta^{(k)}\right]=\left[\theta_{1-2-3}\right] \sum_{i=1}^{N_{v}}\left\{\left[\theta_{4}^{(i)}\right] \sum_{j=1}^{N_{s}}\left[\theta_{5, i}^{(j)}\right]\left[\theta_{6, j}\right]\left[\theta_{7, i, j}^{(k)}\right]\left[\theta_{8, i, j}^{(k)}\right]\right\}
$$

where $k$ indicates a specific point in the target domain, $i$ and $j$ indicate respectively a given vent position (out of the possible $N_{v}$ ) and size class (out of the possible $N_{s}$, see Marzocchi et al., 2010 for more details). The BET_VH tool has been used in other volcanic areas to produce a full probabilistic hazard assessment for ash fall and other volcanic hazardous phenomena (Sandri et al., 2012; 2014). An ongoing improvement of the method aims at performing the production of fully probabilistic hazard curves that include uncertainty bounds, based on the method proposed for seismic hazard by Selva and Sandri (2013). Site-specific hazard curves represent the most complete information about the hazard allowing volcanologists to produce hazard maps at different levels of probability and/or different levels of hazard intensity (SSHAC, 1997). 


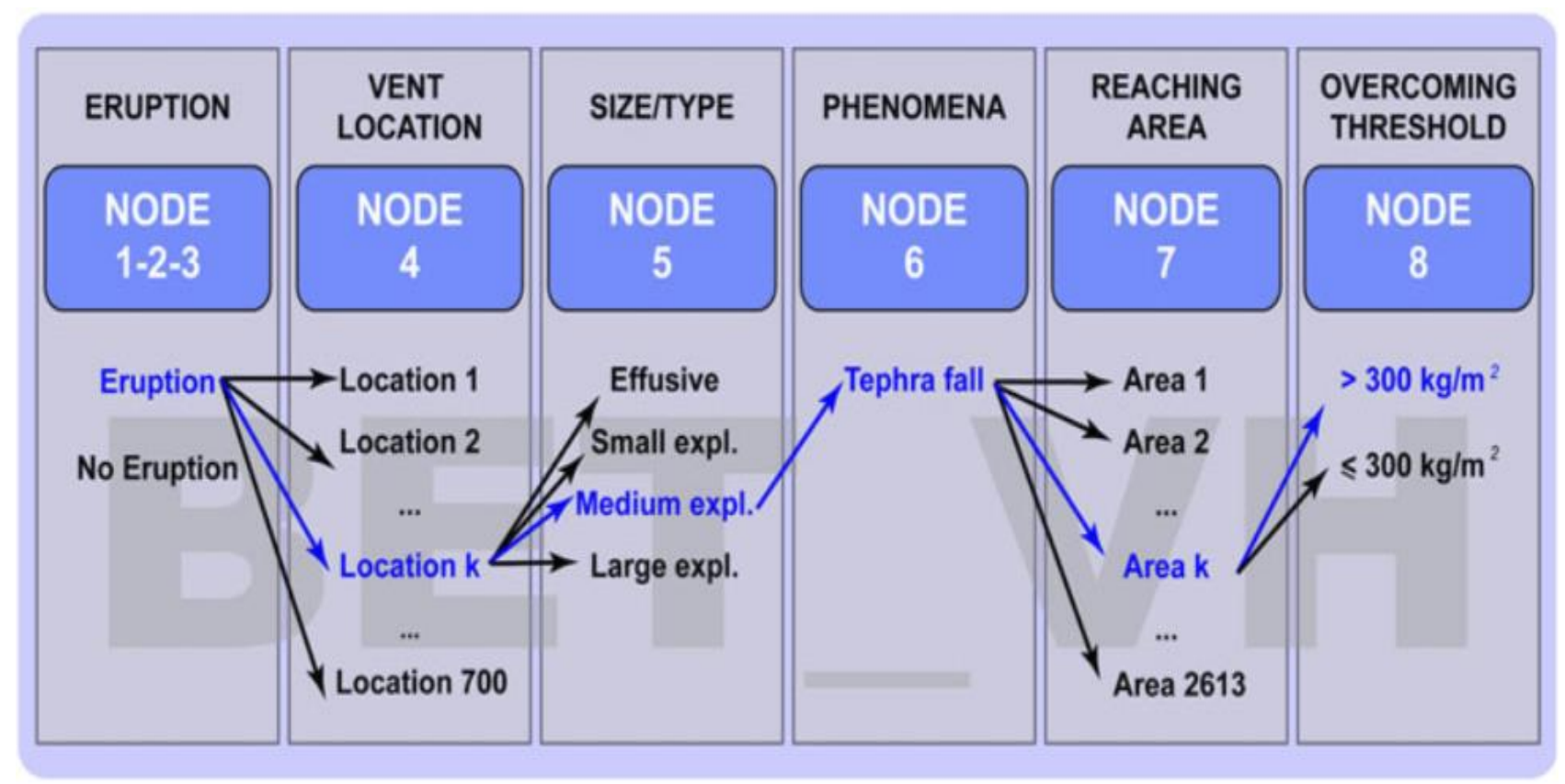

Figure 9: Event tree of the model BET_VH for a specific volcano to evaluate the PVHA for ash fall loads above 300 $\mathrm{kg} / \mathrm{m}^{2}$

Large-scale global or regional approaches to probabilistic ash hazard assessment (Section 4.1) are currently only appropriate for long-term (years to decades) assessment because the current unrest state of each volcano is not taken into account. The advantage of a tool like BET_VH is that it can be used at both the long- and short- (hours to days) timescales.

\subsubsection{Results}

For the factors in Equation 1, a number of previous and ongoing studies have derived appropriate values for longand short-term hazard assessment at Vesuvius and Campi Flegrei:

- For Vesuvius, Marzocchi et al. (2004; 2008) have estimated the eruption probabilities, locations and style (nodes 1 through 5), while Macedonio et al (2008) have used ash dispersal models to estimate the probabilities associated with spatial extent (node 7) and critical thresholds (node $8: 300 \mathrm{~kg} / \mathrm{m}^{2}$ is shown here as example).

- For Campi Flegrei, a significant improvement was achieved by considering all possible eruptive sizes and vents, conditional on the occurrence of an eruption (Selva et al., 2010). This was computed by accounting for the uncertainty in the vent location (node 4: Selva et al., 2012), the eruption style (node 5: Orsi et al., 2009), and the probability weighted dispersion of the ash over impacted areas (nodes 6 through 8: see Figure 10). This kind of approach is particularly useful for large and potentially very explosive calderas, such as Campi Flegrei, for which the position of the vent is critical and can impose a large uncertainty on the final hazard assessment. 


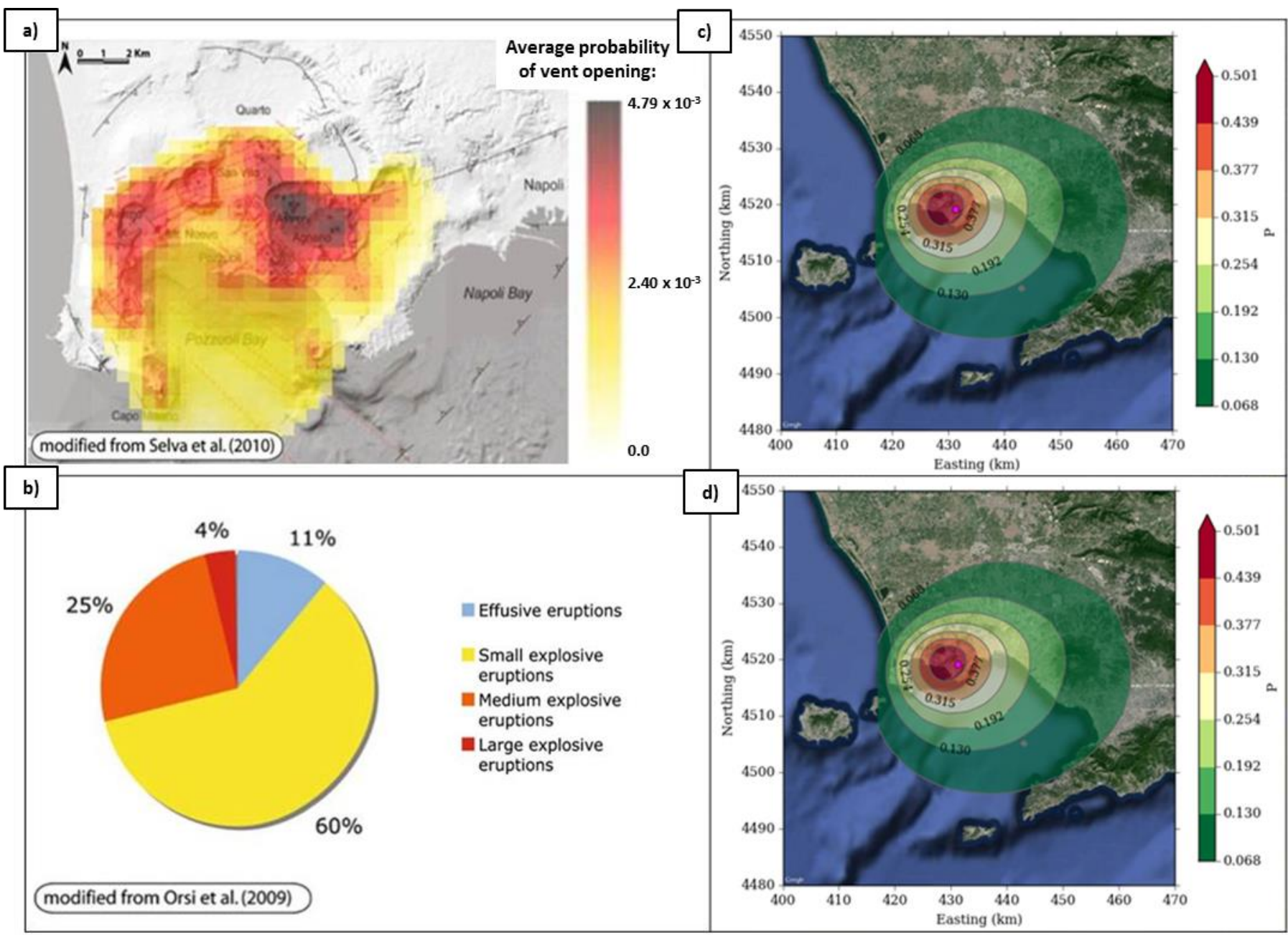

Figure 10: Panel a) and b) show the mean probability of vent opening and possible eruptive sizes at Campi Flegrei, respectively. Panels c) and d) show the mean probability of an ash fall load and a load larger than $300 \mathrm{~kg} / \mathrm{m}^{2}$, respectively, conditional on the occurrence of an eruption at Campi Flegrei from any possible vent location and of any possible size, properly combined according to the probabilities shown in panels a) and b). A loading of $300 \mathrm{~kg} / \mathrm{m}^{2}$ is shown here and is expected to result in significant (>80\%) of weak flat wooden, reinforced concrete and steel roofs (Costa et al., 2009; Zuccaro et al., 2008).

\subsubsection{Discussion}

Despite the recent significant steps towards achieving a full and comprehensive probabilistic ash hazard assessment for the Neapolitan area, much work has still to be done.

- $\quad$ Long-term ash fall hazard assessment

Two ongoing Italian projects (ByMuR, 2010-2014; DPC-V1, 2012-2013) have been working towards providing further improvements in long-term ash hazard assessment for Vesuvius, Campi Flegrei and Ischia. A preliminary merging of the full probabilistic ash fall hazard assessments at Vesuvius and Campi Flegrei for the municipality of Naples is shown in Figure 11. The variability of eruptive parameters within each size class must also be modelled, to evaluate its importance and impact on the final assessment. The production of hazard curves, as mentioned above, is a necessary step if results are to be included into quantitative risk assessment procedures. The assessment of the epistemic uncertainty on the hazard curves represents the most complete results that we aim to achieve. An updated probabilistic volcanic hazard assessment for the municipality of Naples is planned to be ready for the end of the project ByMuR (late 2014) and will consist of hazard curves for a set of confidence levels (regarding epistemic uncertainties), for each cell of the grid covering the municipality of Naples (Figure 11). 


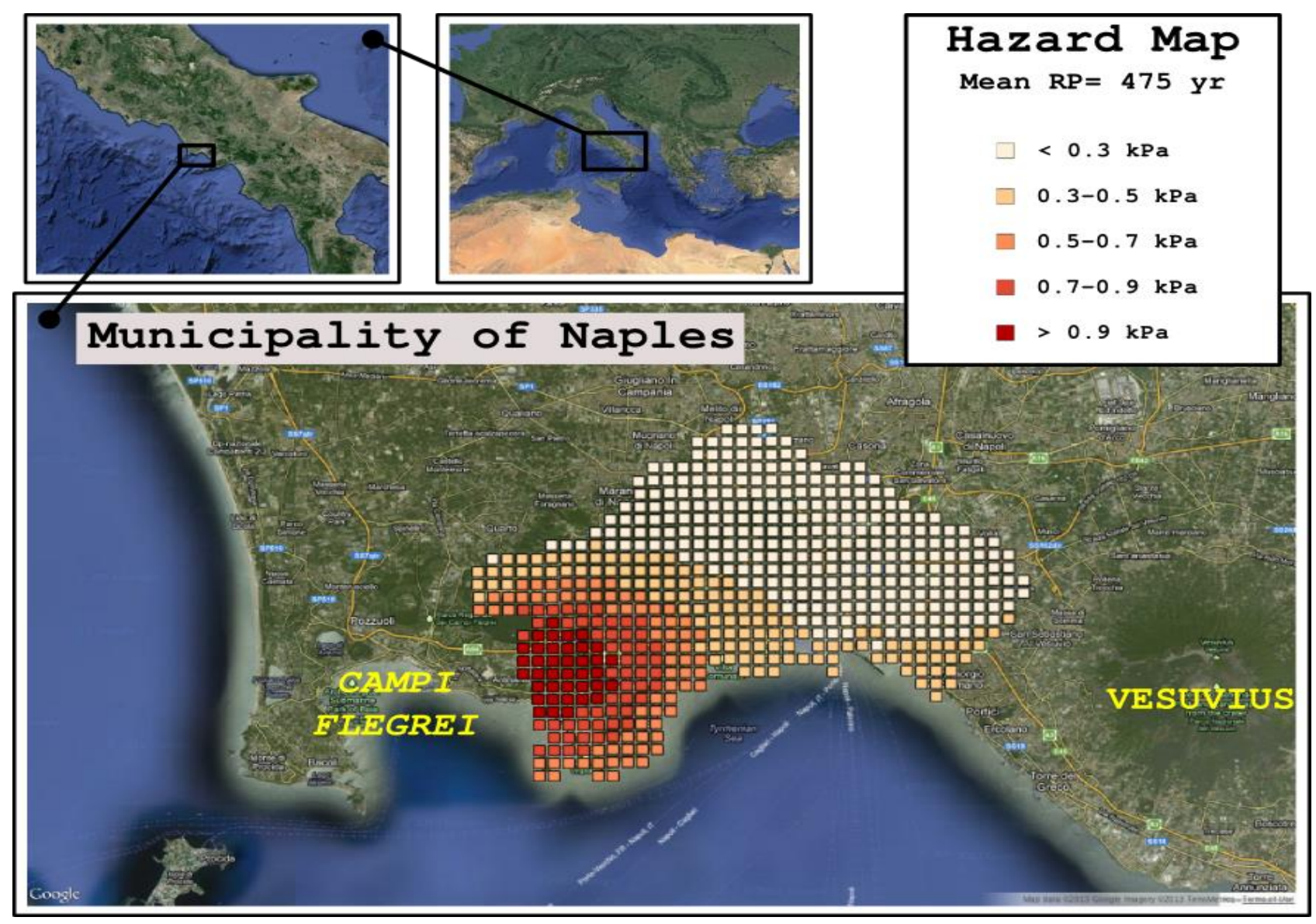

Figure 11: Hazard map (mean) for ash fall loading with an average recurrence interval of 475 years (exceedance probability threshold equal to 0.1 in 50 years), considering both Vesuvius and Campi Flegrei on the municipality of Naples (area shown by pixels).

- Short-term ash fall hazard assessment

Two research projects (the Italian DPC-V2, 2012-2014, and the EC MEDSUV 2013-2015) aim at providing quantitative improvements for short-term ash fall hazard assessment at Vesuvius and Campi Flegrei in order to allow such hazard assessments to be operational for emergency management. This approach can provide a tool of primary importance during potential volcanic unrest episodes and for ongoing eruptions. The tool could be updated frequently (hourly or daily) to account for a rapidly evolving crisis situation, providing crucial information for crisis management. Theoretically, short-term assessments should be based on sound modelling procedures stemming from frequently updated meteorological forecasts and information about the crisis evolution. In addition, the relevance of epistemic uncertainties arising from the forecast of the future eruption dynamics and wind conditions, and from the ash dispersal model, should be estimated.

\section{Ash fall impacts}

Understanding how ash falls can impact communities, built environments and economies, and the consequences with varying hazard intensities, is critical to understanding ash fall risk. In this section, we draw from data collected during and following past eruptions, as well as experimental and theoretical studies, to highlight the impacts an ash fall may have for key sectors of society such as health, infrastructure and the economy. We also discuss how the varied characteristics of volcanic ash and the context, e.g. the timing and duration of an ash fall or the environmental conditions at the time, can influence impacts. Section 4 then builds upon these observations and experiments by identifying approximate thresholds for damage and reduced functionality. While we mostly consider impacts associated with discrete ash falls, we note that remobilisation of ash by weather (e.g. wind, rain, snow) or human actions (e.g. clean-up, movement of vehicles) can lead to repeated impacts over weeks, months or even years after an eruption. 


\subsection{Hazard intensity}

Historically, thickness of ash fall deposits has been the most common parameter used to assess the severity of an ash fall at a site (the hazard intensity) in relation to damage because it is relatively easy to measure in the field or interpret from eyewitness accounts and because most published data use this intensity measure (Wilson et al., 2012b). Most recently, ash loading (in mass per unit area, typically $\mathrm{kg} / \mathrm{m}^{2}$ ) has become a preferred measure of intensity as it is more informative when considering impacts to structures and agriculture and is a common output of numerical ash fall models. Measurements or estimates of load also avoid complications with measuring ash thickness due to ash compaction or rain following deposition. A water-saturated ash deposit can be up to twice the load of a similar thickness of dry ash (Macedonio and Costa, 2012).

\subsection{Ash characteristics}

The quantity of ash (thickness or loading) is not the only mechanism by which ash can cause damage or disruption. In practice, the impacts sustained by societal assets, such as critical infrastructure networks and primary production, are determined by a complex interplay of factors. These include other ash fall characteristics such as ash surface composition and particle size, site specific factors, such as climate, and factors related to the affected assets, such as system design and pre-existing vulnerability (Wilson et al., 2012b). The physical and chemical properties of ash are largely controlled by eruptive dynamics and magma composition, although dispersal conditions, e.g. wind and rain, also play a role. Ash properties can therefore vary among different eruptions and within the same eruption.

Condensation of strong mineral acids (such as $\mathrm{HCl}, \mathrm{HF}$ and $\mathrm{H}_{2} \mathrm{SO}_{4}$ ) in a cooling plume can lead to a strongly-acidic surface coating on freshly-fallen ash (Delmelle et al., 2007). Complex interactions between primary gases and mineral surfaces in fragmenting magma lead to the presence of readily-soluble salts on ash surfaces (Delmelle et al., 2007) which are released upon contact with water or other body fluids (Stewart et al., 2013). The presence of soluble salts may also make freshly-fallen ash highly conductive to electrical currents in certain weather conditions, which leads to a high risk of ash deposition causing disruption to electrical transmission and distribution systems via the mechanism of insulator flashover.

The density and mechanical strength (friability) of individual ash particles affects how difficult it is to remove deposits, for example if ash enters drainage networks and also how easily deposits can be ground down and resuspended by wind or rain. Smaller particles are carried farther downwind from the vent, are more easily eroded and remobilised by wind, and can penetrate smaller openings than larger grains. Penetration of ash particles into the respiratory tract is dependent on particle size. Larger particles ( $>10 \mu \mathrm{m}$ diameter) lodge in the upper airways, while those in the 4-10 $\mu \mathrm{m}$ size range deposit in the trachea and bronchial tubes. Very fine $(<4 \mu \mathrm{m}$ diameter $)$ particles may penetrate deeper into the lungs (Horwell and Baxter, 2006). Small particles can also adhere more readily to vegetation and infrastructure components. Magnetic minerals in some volcanic ashes may also influence adhesion, although there are very few studies on this phenomenon.

\subsection{Context}

As well as the intensity and characteristics of ash falls, their duration and timing within an eruption also strongly determines what impacts may occur, particularly for the agriculture production cycle. In addition to the eruption duration and timing with respect to season, environmental factors such as wind and rain on ash dispersal and remobilisation, will also dictate the level of impact a community experiences. For example, dry, windy environments facilitate remobilisation of ash deposits near the ground which can 'ash-blast' vegetation and cause challenging living conditions for decades after the eruption (e.g. Hudson 1991 eruption: Wilson et al., 2011). Conversely, high precipitation can saturate ash deposits and increase the load causing greater structural and agricultural damage as well as large, potentially damaging mudflows (e.g. Pinatubo eruption 1991: Newhall \& Punongbayan, 1996). Deposits of ash have been observed to form surface crusts which may serve to inhibit water infiltration and soil-gas exchange and increase surface runoff (Blong, 1984). Ash falls onto glaciated or snow-covered areas can act to increase or 
reduce run-off, depending upon the ash fall thickness, with associated consequences for surrounding populated areas (preliminary assessment provided by a Supraglacial Ash fall Likelihood Index: Appendix B).

\subsection{Assessment of ash fall impacts}

The assessment of ash fall impacts is a comparatively underdeveloped field compared to, for example, seismic impact assessment. This is in part because large explosive eruptions impacting populated areas are relatively infrequent and because few comprehensive quantitative impact studies have been carried out. Impacted zones can be dangerous and sometimes inaccessible for long periods. Broadly speaking, three main zones of ash fall impact may be expected, each requiring a different approach to impact management and planning: 1) Destructive and potentially life-threatening (Zone I); 2) Damaging and/or disruptive (Zone II); 3) Mildly disruptive and/or a nuisance (Zone III). These zones are summarised as a cartoon in Figure 12 where physical ash impacts to selected societal assets are depicted against ash deposit thickness - which generally decreases with distance from the volcano source. The more severe impacts depicted in Zones I and II may not eventuate in smaller magnitude eruptions because insufficient ash fall occurs. A further impact zone (Zone IV) could be applied to areas that extend beyond those receiving ash fall, where aviation may be disrupted by airborne ash. For example the Puyehue Cordón-Caulle eruption in Chile in 2011 deposited ash over 75,000 km² (Buteler et al. 2012), primarily in Argentina, but the airborne ash was detected in air sampling equipment in Porto Alegre, Brazil, $2000 \mathrm{~km}$ away (de Lima et al., 2012) and caused flight cancellations around the southern hemisphere, e.g. in south east Australia 10,500 km from the volcano (Lahey, 2012).

Quantitative collection of ash fall impact data began in earnest with the explosive eruption (VEI 5) of Mount St Helens in the USA in 1980. Ash was erupted $23 \mathrm{~km}$ into the atmosphere and dispersed across 11 states (Figure 3; BGVN, 1980) affecting critical infrastructure, health and socio-economic activities (Blong, 1984). More recent collection of quantitative impact data following subsequent eruptions of varying styles and magnitudes in a range of climates, communities, built environments and socio-economic settings now allows more robust impact estimation for future ash falls. Drawing on this available literature, we have identified six primary sectors that are important with reference to ash fall impacts in each of the zones identified in Figure 12 and for which impacts can be approximately related to ash fall thickness. A qualitative overview of ash impacts as a function of thickness is provided for each of these sectors in Tables 2 through 5. Each category is generic and specific impacts will depend strongly on the network or system design characteristics (typology), ash fall volume and characteristics, and the effectiveness of mitigation strategies that are applied. Impacts are considered with reference to ash fall thickness because it is the parameter commonly used as a metric of ash fall magnitude, being most easily measured or estimated in the field. However, as discussed earlier, other ash characteristics may influence or control the impact, and these have been highlighted. Below we provide some recommended eruption case-studies and selected review articles as supplements to Tables 2 through 5:

1) Health: Horwell and Baxter, 2006; VEI 4 eruptions of Eyjafjallajökull and Grímsvötn, Iceland, in 2010 and 2011 (Carlsen 2012a; 2012b); VEI 5 eruption from Mount St Helens, USA, in 1980 (Baxter et al., 1981).

2) Critical infrastructure: Wilson et al. (2012b); Mount St Helens eruption, USA, in 1980 (Blong, 1984); VEI 4 eruption from Puyehue Cordón-Caulle, Chile, in 2011 (Wilson et al. 2012a).

3) Buildings: VEI 4 eruption from Rabaul, Papua New Guinea, in 1994 (Blong, 2003b); VEl 6 eruption from Pinatubo, Philippines, in 1991 (Spence et al., 1996).

4) Agriculture: VEI 3 eruption from Ruapehu, New Zealand, in 1995-1996: (Cronin et al., 1998); VEI 5 eruption from Mt Hudson, Chile, in 1991 (Wilson et al., 2011); Mount St Helens eruption, USA, in 1980 (Cook et al., 1981).

5) Clean-up: VEI 2 eruption from Shinmoedake, Japan, in 2011 (Magill et al., 2013); Mount St Helens eruption, USA, in 1980 (Blong 1984).

6) Economic activities: VEI 3 eruption of Etna, Italy, 2002 to 2003 (Munich-Re, 2007); Pinatubo eruption, Philippines, in 1991 (Newhall and Punongbuyan, 1996). 


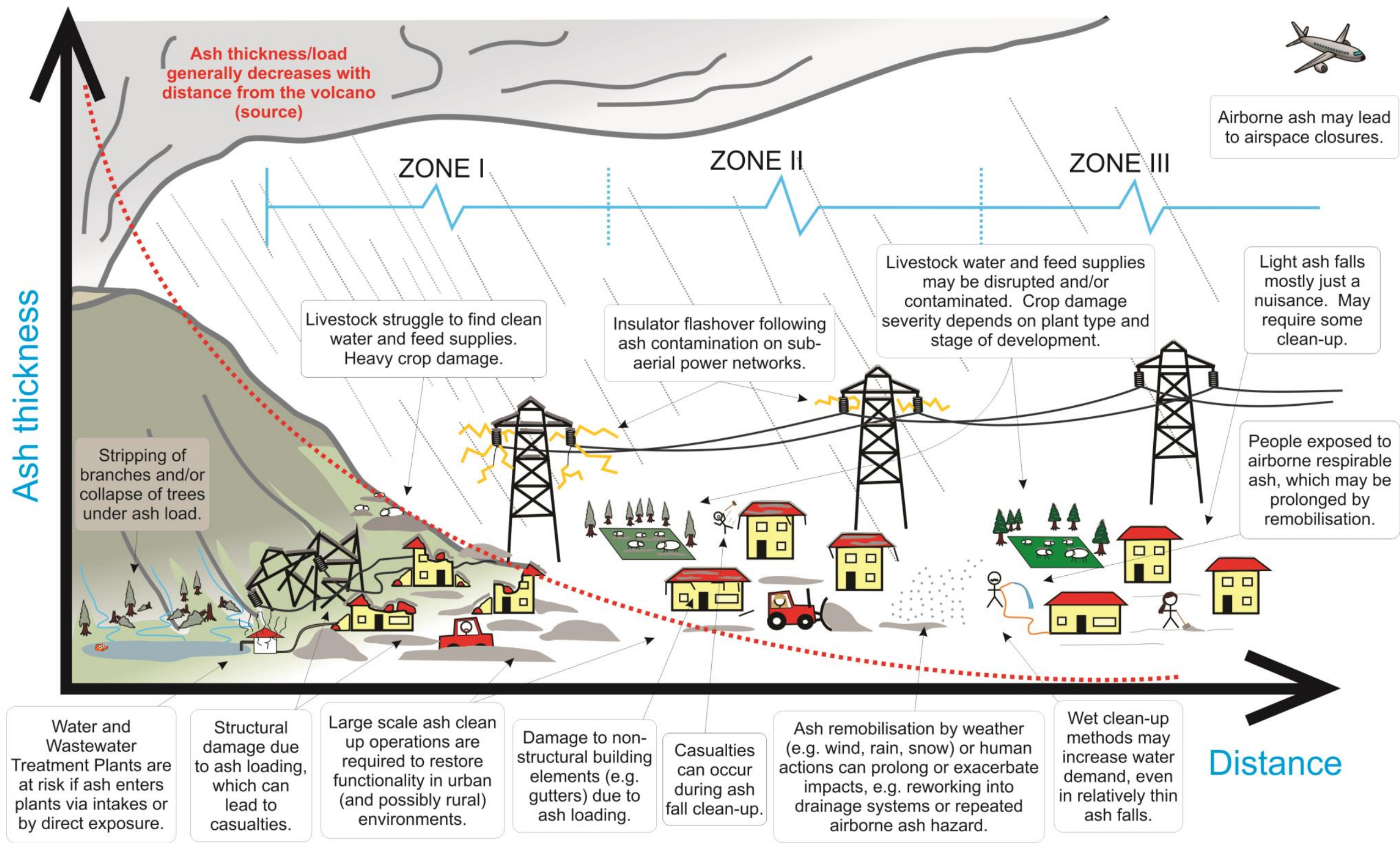

Figure 12: Schematic of some ash fall impacts with distance from a volcano (see Tables 2 through 4). This schematic diagram assumes a large explosive eruption with significant ash fall thicknesses in the proximal zone and is intended to be illustrative rather than prescriptive. Three main zones of ash fall impact are defined: 1) Destructive and potentially life-threatening (Zone I); 2) Potentially harmful to health, damaging and/or disruptive (Zone II); 3) Mildly harmful to health, disruptive and/or a nuisance (Zone III). 
Table 2: Potential impacts from thin ( 1 to $10 \mathrm{~mm}$ ) ash falls, categorised by sector and including key ash characteristics that determine the level of damage or disruption. Note that overloading of a system or network through high-demand or damage can lead to closure, exhaustion or restrictions at critical times, e.g. the exhaustion of water supplies during clean-up activities and these impacts will also exist where thicknesses are greater, potentially with higher severity.

\begin{tabular}{|c|c|c|}
\hline & Potential consequences & $\begin{array}{c}\text { Relevant ash } \\
\text { characteristics }\end{array}$ \\
\hline Public health & $\begin{array}{l}\text { Casualties from fall deposits may occur, e.g. due to people falling from roofs during clean-up. However, the most commonly-reported public } \\
\text { health effects of ash exposure are irritation of the eyes and upper airways and exacerbation of pre-existing respiratory conditions, such as } \\
\text { asthma. Serious health problems (requiring hospitalisation) are rare. A proportion of the population is likely to experience increased levels of } \\
\text { psychological distress due to factors such as increased workload during the eruption and uncertainty about effects on health and livelihoods. } \\
\text { People with pre-existing health vulnerability are more at risk of psychological distress. Individuals who may be exposed to ashy conditions will } \\
\text { require protective clothing and masks. }\end{array}$ & $\begin{array}{l}\text { Particle size; Mineral } \\
\text { composition; Surface area; } \\
\text { Morphology; Soluble salt } \\
\text { burden; Thickness. }\end{array}$ \\
\hline \multirow{3}{*}{ Infrastructure } & $\begin{array}{l}\text { Most road markings obscured; traction and visibility problems; Airports often closed and requiring clean-up. Increased wear of engine and } \\
\text { brakes; possible signal failure on railway lines. }\end{array}$ & \multirow[b]{2}{*}{$\begin{array}{l}\text { Thickness; Particle size; } \\
\text { Mechanical strength. }\end{array}$} \\
\hline & $\begin{array}{l}\text { Possible clogging of air-and water-handling and filtration systems, mechanical and electrical equipment and abrasion damage by waterborne } \\
\text { ash to pump impellers and turbines. Minor short-term increases, particularly in streams and small reservoirs, in elements leached from ash. } \\
\text { Blockage of water intake structures, particularly in streams. Suspended ash in water intakes and sewer lines a possible threat to } \\
\text { water/wastewater treatment plants. 'Open' systems (e.g. with open air sand filters) are more vulnerable. }\end{array}$ & \\
\hline & $\begin{array}{l}\text { Potential flashover of power lines and transformers (particularly in light wet weather conditions). Corrosion and/or abrasion of, e.g. } \\
\text { paintwork, windscreens, metallic elements, some air- and water-handling, mechanical, electrical equipment or engines. Possible damage to } \\
\text { external telecommunication components or power cables. }\end{array}$ & $\begin{array}{l}\text { Soluble salt burden; } \\
\text { Conductivity; Abrasiveness; } \\
\text { Particle size }\end{array}$ \\
\hline Buildings & $\begin{array}{l}\text { No structural damage. Possible infiltration and internal contamination and corrosion of metallic components. Roofing materials may be } \\
\text { abraded or damaged by human actions during ash removal. }\end{array}$ & $\begin{array}{l}\text { Loading; Soluble salt } \\
\text { burden; Abrasiveness. }\end{array}$ \\
\hline \multirow{2}{*}{ Agriculture } & $\begin{array}{l}\text { Effects on livestock expected to be minor but may include irritation of eyes and skin. Animals may ingest ash along with feed but small } \\
\text { quantities are unlikely to cause harm. Cases of fluorosis (if ash contains moderate to high levels of soluble F) are rare but have been reported } \\
\text { for these depths of ash fall. }\end{array}$ & \multirow{2}{*}{$\begin{array}{l}\text { Soluble salt burden; } \\
\text { Particle size; Abrasiveness. }\end{array}$} \\
\hline & $\begin{array}{l}\text { Ash coverage of crops, may lead to aesthetic discolouration and/or acid damage to leaves and fruits and abrasion during clean-up or harvest. } \\
\text { Ash fall may have beneficial effects on soil if ash contains high levels of available plant growth nutrients such as sulphur, and may provide a } \\
\text { beneficial mulching effect. Ash may also encourage or discourage pests and/or pollinating insects. }\end{array}$ & \\
\hline Clean-up & $\begin{array}{l}\text { Minor clean-up required: sweeping of roads, paved areas and roofs/gutters usually sufficient. Ash falls of only a few } \mathrm{mm} \text { depth will generate } \\
\text { large volumes of ash for collection and disposal and clean-up is a time-consuming, costly and resource-intensive operation. Water demand } \\
\text { may remain high for months afterwards if wind-remobilised ash requires dampening. }\end{array}$ & $\begin{array}{l}\text { Thickness; Density; } \\
\text { Abrasiveness. }\end{array}$ \\
\hline Economy & $\begin{array}{l}\text { Some economic activities may increase, e.g. volcano tourism, but most will be disrupted. Disruption to work and travel. Clean-up cost. } \\
\text { Increased maintenance costs (e.g. at water supply plants where sand filter beds may need to be cleaned more frequently). Increased labour } \\
\text { and health and safety requirements. }\end{array}$ & Thickness; Presence. \\
\hline
\end{tabular}


Table 3: Potential impacts from moderate ( 10 to $100 \mathrm{~mm}$ ) ash falls, categorised by sector and including the key ash characteristics that determine the level of damage or disruption. These impacts are in addition to those experienced at lower thicknesses, i.e. Table 2.

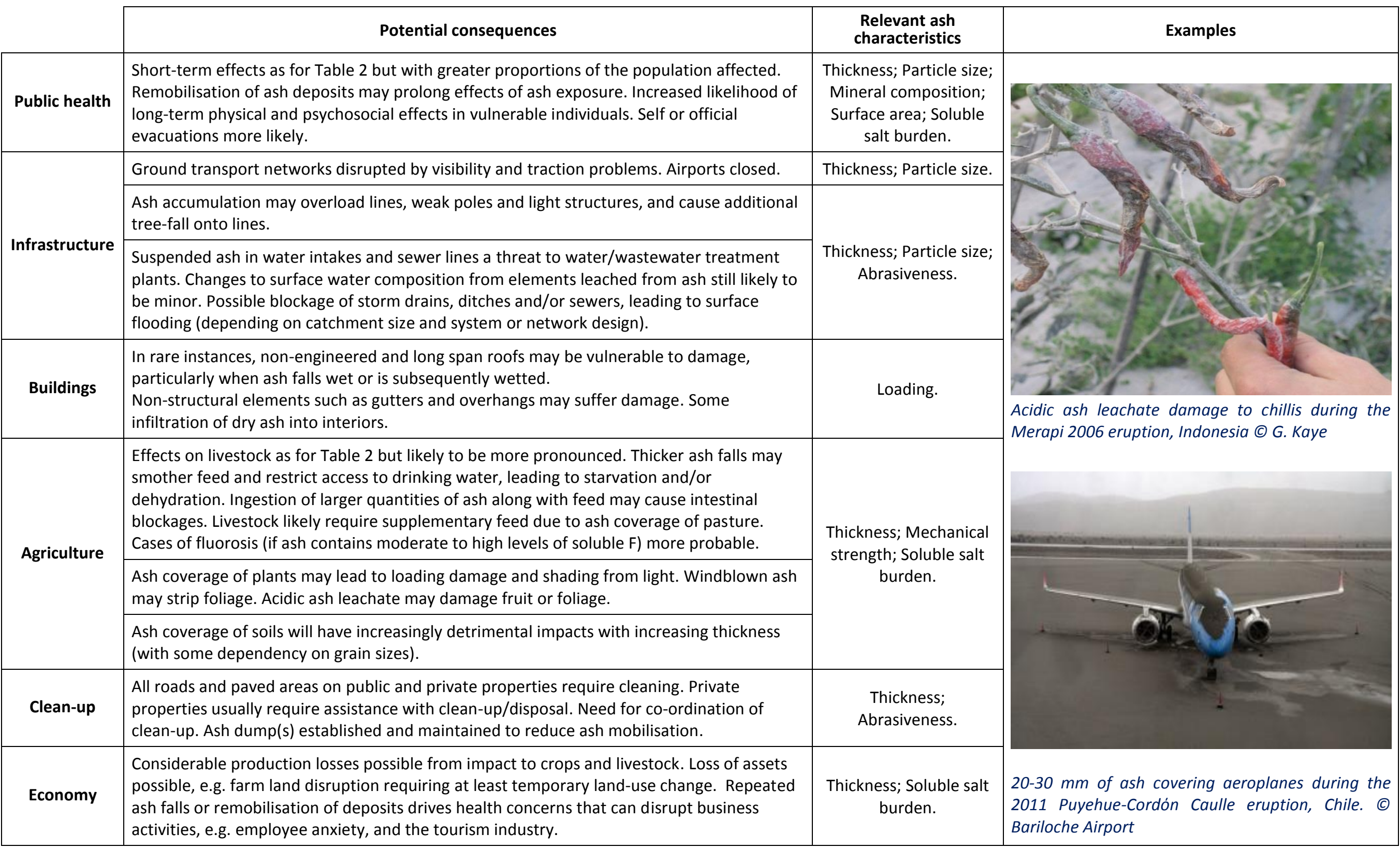


Table 4: Potential impacts from thick (100 to 1,000 mm) ash falls, categorised by sector and including the key ash characteristics that determine the level of damage or disruption. These impacts are in addition to those experienced at lower thicknesses, i.e. Tables 2 and 3.

\begin{tabular}{|c|c|c|c|}
\hline & Potential consequences & $\begin{array}{l}\text { Relevant ash } \\
\text { characteristics }\end{array}$ & Examples \\
\hline Public health & $\begin{array}{l}\text { Casualties (blunt trauma injuries from impact or falling debris, suffocation/inhalation } \\
\text { injuries) possible from collapse of buildings or trees. Prolonged or permanent relocation } \\
\text { possible due to concerns about health and disruption to critical infrastructure and } \\
\text { economic activities. Prolonged exposure to ash leading to high prevalence of effects } \\
\text { described in Table } 2 \text {. Increased levels of stress may manifest as psychological morbidity (e.g. } \\
\text { post-traumatic stress syndrome or depression), Prolonged exposure to ash may increase } \\
\text { risk of chronic silicosis or inflammatory responses. }\end{array}$ & $\begin{array}{l}\text { Particle size; Mineral } \\
\text { composition; Surface } \\
\text { area; Morphology; } \\
\text { Soluble salt burden; } \\
\quad \text { Loading. }\end{array}$ & 8 \\
\hline \multirow{3}{*}{ Infrastructure } & $\begin{array}{l}\text { Transport networks severely affected by reduced traction. Very thick ash falls may create } \\
\text { extra loading on bridges, especially when wet. Substantial and repeated clean-up of sites } \\
\text { required; dry, windy conditions exacerbate remobilisation and drifting. }\end{array}$ & \multirow[t]{2}{*}{$\begin{array}{l}\text { Thickness; Density; } \\
\text { Particle size. }\end{array}$} & \\
\hline & Most generation plants likely to be disrupted. & & \\
\hline & $\begin{array}{l}\text { Major and ongoing damage to water supply intake structures located in streams; blockages } \\
\text { of canals, intake structures and pipes. Blockages of underground drainage leading to } \\
\text { surface flooding. High risk of severe damage to water- and wastewater- treatment plants if } \\
\text { ash enters systems through intakes, or by direct ash fall. }\end{array}$ & $\begin{array}{l}\text { Thickness; Particle } \\
\text { size; Mechanical } \\
\text { strength. }\end{array}$ & \multirow[t]{2}{*}{$\begin{array}{l}\text { Collapse of a weak metal sheet roof under 150-300 } \\
\text { mm of ash during the } 1991 \text { Pinatubo eruption, } \\
\text { Philippines (C) NOAA/NGDC, T.J. Casadevall, USGS }\end{array}$} \\
\hline Buildings & $\begin{array}{l}\text { Non-engineered and long span or low pitched roofs more vulnerable to collapse. } \\
\text { Non-structural elements (such as gutters) likely to be damaged. }\end{array}$ & Loading & \\
\hline \multirow[t]{2}{*}{ Agriculture } & $\begin{array}{l}\text { Burial of pasture and most crops; loading damage to tree crops and shade trees likely. Soil } \\
\text { rehabilitation, e.g. through mixing or removal of the ash, is typically required for agricultural } \\
\text { production to be restored. The buried soil's fertility may wane over time as key soil } \\
\text { processes are broken or inhibited by ash blanket (i.e. water, oxygen and nitrogen cycles). } \\
\text { Damage/burial of farm assets, including machinery, irrigation systems, access-ways, etc. }\end{array}$ & \multirow[t]{2}{*}{$\begin{array}{l}\text { Thickness; Loading; } \\
\text { Density; Particle size. }\end{array}$} & \\
\hline & Tree damage possible in production forests, particularly for those not adapted to snow. & & \\
\hline Clean-up & $\begin{array}{l}\text { As for thinner ash falls, but much larger volumes will require greater resources, time, } \\
\text { repeated and frequent clean-up. Vegetated areas (e.g. parks and gardens) may require } \\
\text { cleaning. }\end{array}$ & Loading; Thickness. & \\
\hline Economy & $\begin{array}{l}\text { Losses associated with business interruption, supply chain failures, reconstruction and } \\
\text { relocation costs and loss of land. Prolonged disruption to economic activities may drive } \\
\text { evacuations and associated direct and indirect economic losses. }\end{array}$ & Loading; Thickness. & $\begin{array}{l}\text { A tractor mixes volcanic ash with the underlying soil } \\
\text { following the } 1991 \text { eruption of Pinatubo in the } \\
\text { Philippines. O C. Newhall, USGS. }\end{array}$ \\
\hline
\end{tabular}


Table 5: Potential impacts from very thick $(>1,000 \mathrm{~mm})$ ash falls, categorised by sector and including the key ash characteristics that determine the level of damage or disruption. These impacts are in addition to those experienced at lower thicknesses, i.e. Tables 2, 3 and 4.

\begin{tabular}{|c|c|c|c|}
\hline & Potential consequences & $\begin{array}{c}\text { Relevant ash } \\
\text { characteristics }\end{array}$ & Examples \\
\hline Public health & $\begin{array}{l}\text { Casualties possible from collapse of buildings or trees (see Table 4). Rescue operations are } \\
\text { likely to be required. Prolonged or permanent relocation possible due to land-use change } \\
\text { from very thick ash deposits. }\end{array}$ & $\begin{array}{c}\text { Thickness; Particle } \\
\text { size; Mineral } \\
\text { composition; Surface } \\
\text { area; Morphology; } \\
\text { Soluble salt burden; } \\
\text { Loading. }\end{array}$ & \\
\hline Infrastructure & $\begin{array}{l}\text { Structural damage to all structures possible. Most infrastructure systems will be damaged } \\
\text { and disrupted for extended periods. Ground transport networks rendered impassable to } \\
\text { most vehicles. Substantial and repeated clean-up of sites required; fluvial remobilisation of } \\
\text { unconsolidated deposits is likely for years to decades; dry, windy conditions exacerbate } \\
\text { remobilisation and drifting. }\end{array}$ & $\begin{array}{l}\text { Thickness; Density; } \\
\text { Particle size; Loading }\end{array}$ & \\
\hline Buildings & Structural damage to most buildings likely. & Loading & \\
\hline Agriculture & $\begin{array}{l}\text { Total burial of crops/pastures, likely requiring land-use change without rehabilitation. The } \\
\text { buried soil's fertility will decrease over time as key soil processes are sealed off. Tree } \\
\text { damage likely in production forests. }\end{array}$ & $\begin{array}{l}\text { Thickness; Loading; } \\
\text { Density; Particle size. }\end{array}$ & \multirow{3}{*}{$\begin{array}{l}\text { Abandoned farmland (buried fence line) following } \\
1991 \text { Hudson eruption, Chile. Photo taken in 2008. (C) } \\
\text { C. Stewart }\end{array}$} \\
\hline Clean-up & $\begin{array}{l}\text { As for thinner falls, but much larger volumes will require greater resources, time and } \\
\text { repeated and frequent clean-up. It may not be economic to undertake a clean-up } \\
\text { operation. }\end{array}$ & Loading; Thickness. & \\
\hline Economy & $\begin{array}{l}\text { Losses associated with business interruption, supply chain failures, reconstruction and } \\
\text { relocation costs and loss of land. Prolonged disruption to economic activities may drive } \\
\text { evacuations and associated direct and indirect economic losses. }\end{array}$ & Loading; Thickness. & \\
\hline
\end{tabular}


Thick ash falls (Zone I, Tables 4 and 5) can cause structural damage to buildings and infrastructure, with associated casualties. They can also bury crops and create major clean-up demands, but are typically confined to within tens of kilometres of the vent. By contrast, relatively thin falls of a few millimetres (Zone III: Table 2) can occur over very large areas disrupting transport and causing significant disruption to everyday activities. For example, the 1995/96 eruptions of Ruapehu volcano, New Zealand, were small (VEI 3), but still covered a large proportion of the North Island with thin ash falls of $<1-3 \mathrm{~mm}$. Effects included significant disruption and damage to aviation, a hydro-electric power generation facility, electricity transmission lines, water supply networks, wastewater treatment plants, agriculture and the tourism industry. The total cost of the eruption was estimated to be approximately NZ\$130 million (US\$ 91 million), in 1996 value (Johnston et al., 2000). Even the threat of ash fall can be sufficient to generate public concern with losses associated with precautionary mitigation strategies, e.g. procurement and distribution of face masks.

\subsubsection{Social impacts}

In addition to the physical and health impacts associated with ash falls, affected communities can experience considerable direct and indirect social impacts. These impacts are difficult to relate to any one hazard intensity measure and often highly context- and circumstance-specific. For example, one manifestation of the economic hardship and anxiety associated with the 1995-1996 eruptions of Ruapehu volcano was that communities at the base of the volcano experienced increased levels of post-traumatic stress in school-aged children (Ronan, 1997). Socio-economic impacts such as these, and particularly those that are indirect, can develop over a long period of time and can be difficult to predict, plan for and assess; they are likely to be more pronounced in long-duration crises with continuous or intermittent ash falls or extended remobilisation episodes (e.g. Sword-Daniels et al., 2014). As with other natural hazards, socio-economic impacts are often felt disproportionately within and between communities due to a range of pre-existing and inter-related socio-cultural, political and economic vulnerabilities (e.g. gender, age, ethnicity, physical ability, social capital, economic status, political representation, health and education) (Wisner et al., 2012). For example, groups marginalised due to ethnic or economic status may live in higher risk areas in unsuitable housing (Gaillard, 2006), e.g. rural dwellings of weak construction, and often experience considerable financial hardship due to hazard impacts. Communities exposed to any magnitude of ash fall commonly report anxiety about the health impacts of inhaling or ingesting ash (and impacts on animals and property), which may lead to temporary (and sometimes unnecessary) socio-economic disruption (e.g. evacuation, school closures, cancellations).

Communities affected by one or few large ash falls within a short duration - often rare, low probability, events -may have limited experience, tools or resources to react leading to exacerbation of the original impacts and a comparatively poor capacity to cope. Conversely, chronic ash impacts (through repeated eruptions or ash fall remobilisation) can drive adaptation and mitigation activities. For example, Kagoshima city in Japan has been frequently affected by ash from Sakura-jima volcano over the last 50 years but structural adaptations and mitigation measures have successfully reduced the disruption of ongoing ash falls (Durand et al., 2001). The city has modified critical services (such as covering waste-water treatment plants and jacketing electrical insulators to reduce the likelihood of flashover), changed building designs to prevent ash ingress and sedimentation, and invested in ash clean-up equipment and development of plans for clean-up operations. As such, the city copes relatively well with the frequent ash falls and experiences little disruption (Durand et al., 2001).

In summary, forecasting how a community will respond to ash falls is complex and will depend upon many factors including individual and collective experiences, socio-economic setting, the vulnerability of community assets to damage and disruption, the level of planning, leadership, and social capital. 


\section{Estimating vulnerability}

Empirical evidence for the impacts of volcanic eruptions is relatively limited for the reasons given in Section 3 . Experimental data (e.g. Oze et al., 2014) are also limited, and, where available, refer exclusively to materials and the building codes or standards of the tested component or system. In the absence of empirical or experimental data, theoretical calculations of the response of components, systems or networks to hazard parameters can add to the availability of quantitative vulnerability information (e.g. Spence et al., 2005), but may be subject to various uncertainties. As a result, vulnerability estimates for volcanic impacts are typically less robust than those for earthquake or wind, for example, because the research field is relatively new and because volcanoes exhibit relatively low recurrence intervals. However, volcanic eruptions have the potential to cause more widespread highconsequence impacts. Reducing ash fall risk requires an understanding of the breadth and severity of potential impacts and understanding the vulnerability of key community assets to ash fall is fundamental in assessing potential impacts.

A commonly used approach is to categorise impacts by sector (see Section 3) and consider the relationship between hazard intensity (in this case ash thickness) and damage, or disruption state, for each sector. In Tables 6 through 8, we present some broad guides that relate dry ash thickness (as the ash fall characteristic most easily measured and observed in the field) to critical infrastructure, buildings and agriculture. We consider these to be the sectors most relevant to how communities cope with ash fall and for which there is empirical evidence to inform assignment of vulnerability values. We note that wet ash has a substantially higher density than dry ash, which influences loading: saturated ash can as much as double the load the deposit imparts, such that the damage states reported in Table 7 may occur under half the thicknesses of dry ash. Brief descriptions of likely disruption (impact on functionality) and damage are outlined for each state (D0 through D5), and ordered by increasing dry ash fall thicknesses for severe damage or disruption (D4). We outline approximate costs (as a proportion of replacement cost) for roofs damaged by ash fall (following Blong, 2003a and unpublished studies around Vesuvius, Italy). For damage states with no damage, there may still be associated costs. For example, closure of airports because of airborne trace ash falls can result in significant loss of revenue. Losses may also result from precautionary risk management activities, e.g. covering water supplies, precautionary evacuations or loss of business activity, associated with the threat of ash fall. At higher hazard intensities, where losses may be expected due to physical damage, there may also be a significant cost associated with management and assessment. For example, of the approximately NZ\$130 million (US\$ 91 million in 1996) losses associated with the 1995-1996 eruptions of Ruapehu volcano in New Zealand, around NZ\$ 6 million (US\$ 4.2 million) were attributed to management of the crisis and subsequent damage assessment (Johnston et al., 2000).

The sectors shown in Tables 6 through 8 are those for which ash fall thickness is an appropriate measure of hazard intensity relative to damage and functional state. This list is therefore not exhaustive, but highlights some key sectors that are expected to suffer damage or disruption under ash falls. We deliberately excluded some sectors that are vulnerable to ash impacts, such as water treatment plants, because damage is not proportionally related to ash fall thickness due to complex and variable system and network design.

Minimal structural damage may be expected below about $100 \mathrm{~mm}$ of ash fall, although cleaning and repair of critical infrastructure and building interiors and fittings such as air-conditioning units, in addition to the interruptions associated with their reduced functionality, could be costly and disruptive (Tables 6 and 7). Depending upon when an ash fall occurs (the worst times being during the juvenile growing stage and just before and during harvest), thicknesses of around $100 \mathrm{~mm}$ may be associated with total loss of some crops and very little disruption for more robust agricultural types such as forestry (Table 8). Machinery used for harvest and transportation of horticultural and forestry crops will be adversely affected. Above around $300 \mathrm{~mm}$ of ash fall, we may expect to see changes in land use and potentially indefinite closure of assets becoming an issue. 
Table 6: Approximate median (and interdecile) hazard intensities (using dry ash thickness as a proxy) that relate to key damage and functionality states for a range of critical infrastructure. Water and telecommunication networks are not included here because damage states are difficult to relate them to a single hazard intensity, i.e. thickness. The response of a system or network to ash fall thicknesses will depend upon the system/network design and type, its components and the characteristics of the ash fall.

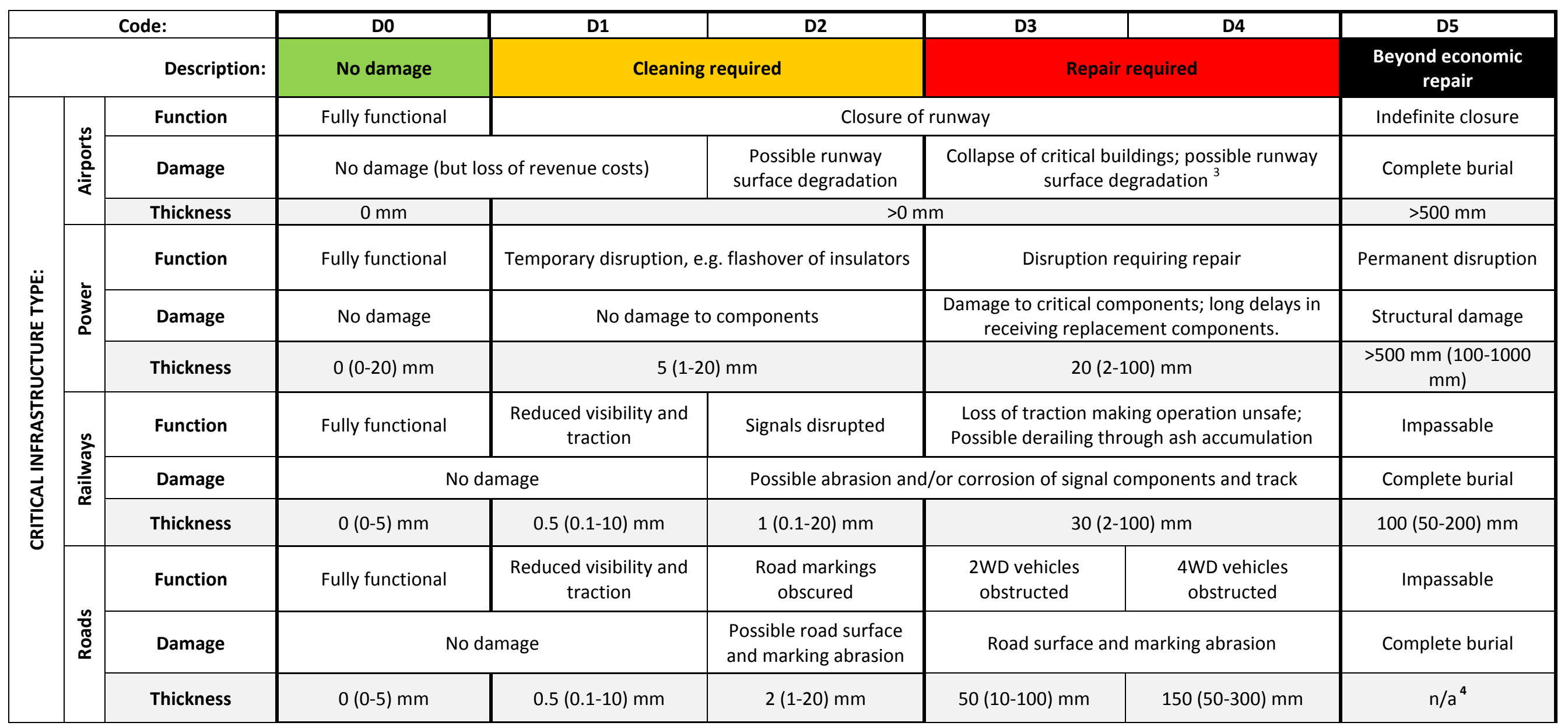

\footnotetext{
${ }^{3}$ Rarely observed

${ }^{4}$ Usually, thick ash deposits can be compacted and a road reinstated
} 
Table 7: Approximate median (and interdecile) hazard intensities that relate to key damage and functionality states for a range of generic roof types (following Spence et al., 2005 and Jenkins et al., 2014). Approximate cost ratios are estimated, following the work of Blong, 2003a and unpublished studies around Vesuvius, Italy ${ }^{5}$. Dry ash fall thickness (in $\mathrm{mm}$ ) is used as a proxy for hazard intensity and a load density of $1000 \mathrm{~kg} / \mathrm{m}^{2}$ is assumed. A saturated ash deposit would result in the damage states identified at as little as half the suggested thicknesses.

\begin{tabular}{|c|c|c|c|c|c|c|}
\hline & Code: & DO & D1 & D2 & D4 & D5 \\
\hline & Description: & No damage & Minor/basic repair required & $\begin{array}{l}\text { Moderate repair } \\
\text { required }\end{array}$ & Major/specialist repair required & Beyond economic repair \\
\hline & Function: & Functional & $\begin{array}{l}\text { Repeated clean-up required; } \\
\text { Some loss of functionality for } \\
\text { some contents and fittings }\end{array}$ & \multicolumn{2}{|c|}{$\begin{array}{l}\text { Ash infiltration or threat of roof and/or wall collapse may prohibit } \\
\text { habitation }\end{array}$} & Retired \\
\hline \multicolumn{2}{|c|}{ Cost (\% of replacement cost): } & $0-1$ & $1-5$ & $5-20$ & $20-60$ & $>60$ \\
\hline \multicolumn{2}{|r|}{ Structural damage: } & No damage & No damage & $\begin{array}{l}\text { No damage to principal } \\
\text { roofing supports }\end{array}$ & $\begin{array}{c}\text { Partial or complete failure of the } \\
\text { supporting structure, e.g. battens or } \\
\text { trusses; Partial or moderate damage to } \\
\text { the vertical structure }\end{array}$ & $\begin{array}{l}\text { Collapse of roof and } \\
\text { supporting structure over } \\
50 \% \text { of roof area; External } \\
\text { walls may be destabilised }\end{array}$ \\
\hline \multicolumn{2}{|c|}{ Non-structural damage: } & No damage & $\begin{array}{l}\text { Minor damage to roof } \\
\text { coverings, e.g. abrasion and } \\
\text { corrosion of metallic roofs. }\end{array}$ & $\begin{array}{l}\text { Potential damage to } \\
\text { gutters and roof } \\
\text { covering, e.g. excessive } \\
\text { bending, and overhangs }\end{array}$ & $\begin{array}{c}\text { Severe damage or partial collapse of roof } \\
\text { overhangs; Collapse or partial collapse of } \\
\text { roof covering }\end{array}$ & $\begin{array}{l}\text { Partition wall/s destroyed in } \\
\text { some cases }\end{array}$ \\
\hline \multicolumn{2}{|c|}{ Contents and fittings: } & $\begin{array}{l}\text { Some infiltration } \\
\text { of ash possible }\end{array}$ & $\begin{array}{c}\text { Ash infiltration and potential } \\
\text { damage to fittings, e.g. air- } \\
\text { con, and appliances }\end{array}$ & \multicolumn{2}{|c|}{ Variable levels of contamination and damage } & $\begin{array}{l}\text { Damage to most contents } \\
\text { and fittings is irreversible, or } \\
\text { salvage is uneconomical }\end{array}$ \\
\hline \multirow{4}{*}{ 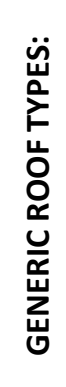 } & $\begin{array}{l}\text { Timber board on weak } \\
\text { timber supports }\end{array}$ & \multirow{4}{*}{$1 \mathrm{~mm}$ ? } & \multirow{4}{*}{$10 \mathrm{~mm}$ ? } & \multicolumn{3}{|c|}{$200 \mathrm{~mm}(100-400 \mathrm{~mm})^{6}$} \\
\hline & $\begin{array}{l}\text { Tiles on timber } \\
\text { supports }\end{array}$ & & & \multicolumn{3}{|c|}{$300 \mathrm{~mm}(150-600 \mathrm{~mm})^{6}$} \\
\hline & $\begin{array}{l}\text { Modest sheeting on } \\
\text { timber supports }\end{array}$ & & & \multicolumn{3}{|c|}{$300 \mathrm{~mm}(150-600 \mathrm{~mm})^{6}$} \\
\hline & $\begin{array}{l}\text { Domestic reinforced } \\
\text { concrete }\end{array}$ & & & \multicolumn{3}{|c|}{$700 \mathrm{~mm}(400-1400 \mathrm{~mm})^{6}$} \\
\hline
\end{tabular}

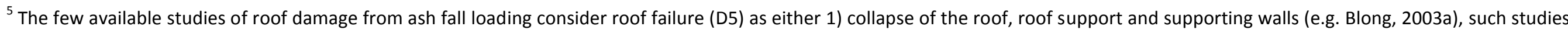

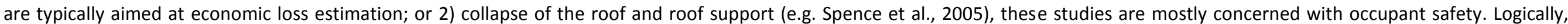

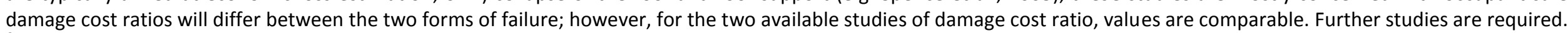

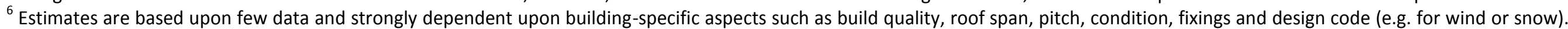
These are likely to vary significantly between and within countries and will be larger when considering a more comprehensive form of failure, i.e. collapse of the entire building. 
Table 8: Approximate median (and interdecile) hazard intensities (using dry ash thickness as a proxy) that relate to key levels for loss of production for a range of agriculture types. These hazard-loss of productivity relationships are based on expert judgement and very few empirical and experimental data. Impacts assume that the crops are in the growing stage (a worst-case impact); season modifiers will allow impacts during other periods of the growing cycle to be accounted for. These estimates are thus intended as broad guidelines and should be refined for individual cases and conditions.

\begin{tabular}{|c|c|c|c|c|c|c|c|c|}
\hline \multicolumn{3}{|c|}{ Code: } & D0 & D1 & D2 & D3 & D4 & D5 \\
\hline \multicolumn{3}{|c|}{ Description: } & No damage & $\begin{array}{l}\text { Disruption to harvest } \\
\text { operations and } \\
\text { livestock grazing of } \\
\text { exposed feed }\end{array}$ & $\begin{array}{c}\text { Minor productivity } \\
\text { loss: less than } 50 \\
\text { \%/crop }\end{array}$ & $\begin{array}{l}\text { Major productivity } \\
\text { loss: more than } 50 \\
\text { \%/crop; Remediation } \\
\text { required }\end{array}$ & $\begin{array}{l}\text { Total crop loss; } \\
\text { Substantial } \\
\text { remediation required }\end{array}$ & $\begin{array}{l}\text { Major rehabilitation } \\
\text { required/ } \\
\text { Retirement of land }\end{array}$ \\
\hline \multirow{5}{*}{ 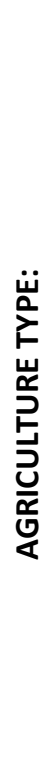 } & \multirow{2}{*}{$\begin{array}{c}\text { Horticulture } \\
\text { \& Arable }\end{array}$} & $\begin{array}{c}\text { Ground } \\
\text { Crops \& } \\
\text { Arable }\end{array}$ & $\begin{array}{c}0 \mathrm{~mm} \\
(0-20 \mathrm{~mm})\end{array}$ & $\begin{array}{c}1 \mathrm{~mm} \\
(0.1-50 \mathrm{~mm})\end{array}$ & $\begin{array}{c}5 \mathrm{~mm} \\
(1-50 \mathrm{~mm})\end{array}$ & $\begin{array}{c}50 \mathrm{~mm} \\
(1-100 \mathrm{~mm})\end{array}$ & $\begin{array}{c}100 \mathrm{~mm} \\
(25-200 \mathrm{~mm})\end{array}$ & $\begin{array}{c}300 \mathrm{~mm} \\
(100-500 \mathrm{~mm})\end{array}$ \\
\hline & & $\begin{array}{l}\text { Tree } \\
\text { Crops }\end{array}$ & $\begin{array}{c}0 \mathrm{~mm} \\
(0-20 \mathrm{~mm})\end{array}$ & $\begin{array}{c}1 \mathrm{~mm} \\
(0.1-50 \mathrm{~mm})\end{array}$ & $\begin{array}{c}5 \mathrm{~mm} \\
(1-50 \mathrm{~mm})\end{array}$ & $\begin{array}{c}50 \mathrm{~mm} \\
(1-100 \mathrm{~mm})\end{array}$ & $\begin{array}{c}200 \mathrm{~mm} \\
(5-500 \mathrm{~mm})\end{array}$ & $\begin{array}{c}300 \mathrm{~mm} \\
(200-500 \mathrm{~mm})\end{array}$ \\
\hline & \multicolumn{2}{|c|}{ Pastoral } & $\begin{array}{c}0 \mathrm{~mm} \\
(0-20 \mathrm{~mm})\end{array}$ & $\begin{array}{c}3 \mathrm{~mm} \\
(0.1-50 \mathrm{~mm})\end{array}$ & $\begin{array}{c}25 \mathrm{~mm} \\
(1-70 \mathrm{~mm})\end{array}$ & $\begin{array}{c}60 \mathrm{~mm} \\
(20-150 \mathrm{~mm})\end{array}$ & $\begin{array}{c}100 \mathrm{~mm} \\
(30-200 \mathrm{~mm})\end{array}$ & $\begin{array}{c}300 \mathrm{~mm} \\
(100-500 \mathrm{~mm})\end{array}$ \\
\hline & \multicolumn{2}{|c|}{ Paddies } & $\begin{array}{c}0 \mathrm{~mm} \\
(0-50 \mathrm{~mm})\end{array}$ & $\begin{array}{c}1 \mathrm{~mm} \\
(0.1-50 \mathrm{~mm})\end{array}$ & $\begin{array}{c}30 \mathrm{~mm} \\
(1-75 \mathrm{~mm})\end{array}$ & $\begin{array}{c}75 \mathrm{~mm} \\
(20-300 \mathrm{~mm})\end{array}$ & $\begin{array}{c}150 \mathrm{~mm} \\
(75-300 \mathrm{~mm})\end{array}$ & $\begin{array}{c}300 \mathrm{~mm} \\
(100-750 \mathrm{~mm})\end{array}$ \\
\hline & \multicolumn{2}{|c|}{ Forestry } & $\begin{array}{c}0 \mathrm{~mm} \\
(0-75 \mathrm{~mm})\end{array}$ & $\begin{array}{c}5 \mathrm{~mm} \\
(0.1-75 \mathrm{~mm})\end{array}$ & $\begin{array}{c}200 \mathrm{~mm} \\
(20-300 \mathrm{~mm})\end{array}$ & $\begin{array}{c}1000 \mathrm{~mm} \\
(100-2000 \mathrm{~mm})\end{array}$ & $\begin{array}{c}1500 \mathrm{~mm} \\
(100->2000 \mathrm{~mm})\end{array}$ & $?$ \\
\hline
\end{tabular}

${ }^{7}$ Land will likely only be retired if there is an alternative commodity source. Where there are no alternatives, farmers need to change production and manage poorer and fewer produce. 
In reality, vulnerability to ash fall impacts is dependent on building or infrastructure condition, construction, maintenance, network design, ash volume and particle characteristics, as well as the effectiveness of applied mitigation strategies. The values provided in Tables 6 through 8 are intended as broad indicators only and are subject to significant uncertainty; few empirical data are available and, by necessity, vulnerability studies are typically supplemented by expert judgement. A number of assumptions have been made in these impact estimates: namely, that assets were subject to one discrete ash fall event; ash was not removed during deposition (either by wind, water or human actions); and no mitigation actions had been taken prior to impact (e.g. internal strengthening of the building). The hazard-damage/disruption relationships shown here are based on few data and assume generic building types, systems and networks of average condition, design and construction.

Vulnerability estimates are thus subject to significant uncertainty and intended as broad guidelines based on the evidence available, with more detailed assessment suggested for individual cases and conditions; the generalisations in Tables 2 through 5 and 6 through 8 should be considered with this caveat in mind. The approach is simplistic and does not capture system interdependence, i.e. the relationships and dependencies between affected sectors (Meheux et al., 2007). An understanding of how each component or impact-area interfaces and is connected with others is critical for addressing vulnerability. The loss of one component or node in a system may create cascading effects to other sectors, causing dynamic vulnerability of the system and its environment. For example, ash-blocked storm-water drains can cause secondary flooding that may recur for weeks or months following an eruption, until the system is cleared of ash. The secondary flooding can cause road access problems, and can prevent access to impacted infrastructure for maintenance or repair (Wilson et al. 2012). In this way, the ash fall impacts on the water infrastructure system can have a knock-on effect to the functionality of transport systems. The approach used in Tables 6-8 also does not recognise the (sometimes complex) multi-hazard environment which may emerge following an ash fall, such as where a house roof survives a thick ash fall loading, but ash remobilised as lahars impact the house making it unsafe for habitation (Blong, 2003a).

Vulnerability estimates are typically the weakest part of a risk model and, wherever possible, detailed local studies of exposed assets and their vulnerability (e.g. Zuccaro et al., 2008; Galderisi et al., 2013) should be carried out before a full risk assessment is undertaken. In many parts of the world the failure, disruption or reduced functionality of infrastructure is likely to have a larger impact on livelihoods and the local economy than direct damage to buildings and infrastructure. In some cases impacts can exacerbate existing economic, social or agronomic decline (e.g. Wilson et al., 2011). We therefore recommend that future physical vulnerability assessments for volcanic areas always include surveys of exposed buildings and infrastructure, and any interdependencies, as well as considering direct and indirect socio-economic impacts.

\section{Looking ahead}

This is the first time that volcanic hazard has been included in a UNISDR Global Assessment Report and in this technical background paper we have concentrated on volcanic ash, as the volcanic hazard that most frequently affects large populations and assets. This technical background paper has been reviewed by the Global Volcano Model network (GVM) and the International Association of Volcanology and Chemistry of the Earth's Interior (IAVCEI), who wish to highlight the importance of ash as a far-reaching volcanic hazard that can disrupt human activities even at very small intensities. Volcanic hazard and risk research is a rapidly growing and evolving field and ongoing research is working towards better quantification and communication of the uncertainties associated with current approaches. The broad overviews and examples illustrated in this paper are only some of the many strands of volcanic hazard and risk research being undertaken by the volcanology community. For example, the CAPRA risk modelling platform (ecapra.org) has been used to provide preliminary estimates of potential building damage around active volcanoes in the Asia-Pacific Region using simplified volcanic hazard outputs from a statistical emulator (see Case Study box: Unravelling volcanic ash fall hazard for risk-managers). A more local example is the KazanRisk loss model (riskfrontiers.com/kazanrisk.htm), which uses numerical dispersal modelling of ash fall in 
Greater Tokyo to estimate potential losses associated with building damage, clean-up and reductions in agricultural productivity.

\section{Unravelling volcanic ash fall hazard for risk-managers}

A.N. Bear-Crozier, V. Miller, V. Newey, N. Horspool, and R. Weber

With the objective of examining volcanic ash fall hazard and components of the associated risk on a regional-to-global scale, the CAPRA platform is utilised in GAR15 (www.ecapra.org; CIMNE et al., 2013). Preliminary volcanic ash fall hazard information is combined with regional vulnerability curves for structural damage to buildings (Maqsood et al., 2014) and exposure information (De Bono, 2013), in requisite formats for the CAPRA platform (ash fall-load in $\mathrm{kg} / \mathrm{m}^{2}$ at $5 \mathrm{~km}$ spacing for each average return period). Up-scaling local ash dispersal modelling methods to the regional-toglobal scale is both time consuming and computationally intensive. The Probabilistic Volcanic Ash Hazard Analysis (PVAHA) methodology was developed and implemented at Geoscience Australia (Bear-Crozier et al., 2014) for determining ash fall hazard, consistent with the objectives and constraints outlined above. PVAHA considers a multitude of volcanic eruption occurrences using associated ash fall-load attenuation relationships (determined for a range of parameters including eruption magnitude, column height, duration, particle size distribution, wind velocity) the results from each applicable event are integrated to derive a preliminary annual exceedance probability for each site of interest.

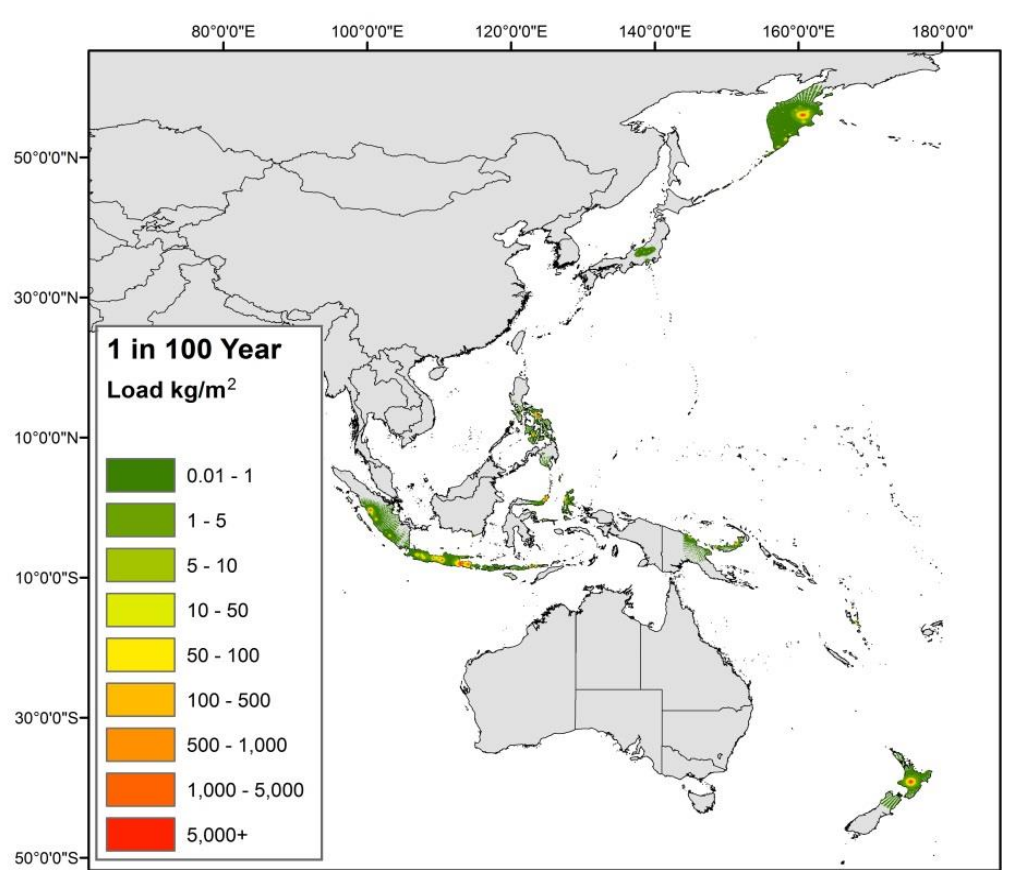

Estimated maximum ash fall-load for the Asia-Pacific Region at the 100 year average return period.

In the Asia-Pacific Region 276 volcanoes were identified and statistically characterised in order to generate an emulated catalogue of volcanic eruptions. Sites were identified using a $5 \mathrm{~km}$ grid extending to a $500 \mathrm{~km}$ distance from each volcano, a total of 178,935 sites covering $\sim 4,600,000 \mathrm{~km}^{2}$ of the region (Bear-Crozier et al., 2014). The influence of wind direction on the

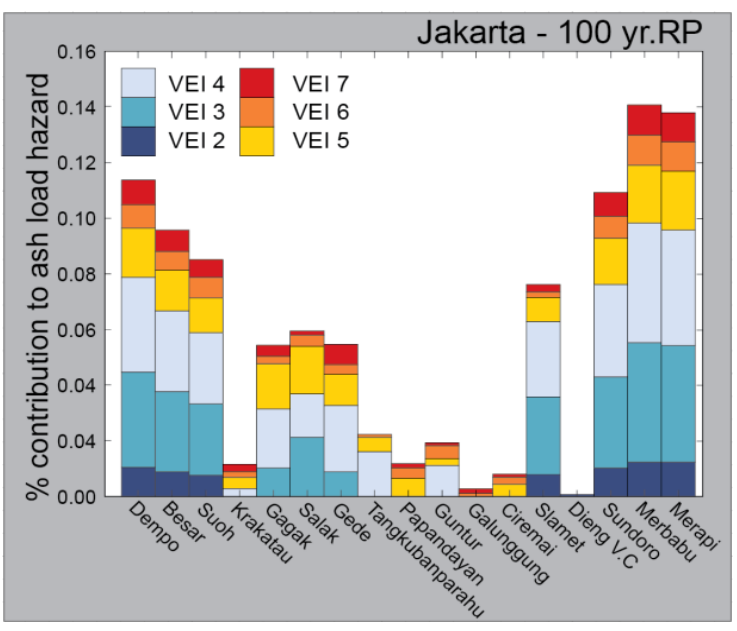

Disaggregating the percentage contribution to ash fall-load in Jakarta from volcanoes around Indonesia for the 100 year average return period distribution of the ash fall-load was greatly simplified, with each direction assumed to have an equal likelihood; therefore hazard and risk will be underestimated in downwind areas and overestimated upwind of the volcano. The preliminary hazard curves of annual probability of exceedance, and (the inverse) average return periods, versus ash fallload $\left(\mathrm{kg} / \mathrm{m}^{2}\right)$ were calculated at each site, with 12 return periods provided for integration into the CAPRA model (see above for 100 year return period results). Calculating hazard curves of annual probability of exceedance versus ash fall load at individual sites allows for disaggregation of the hazard results by, e.g., magnitude, distance or source at each site, which is a useful tool for analysing risk at a site of interest e.g. a densely populated city or piece of critical infrastructure (see left for a preliminary example showing disaggregation of hazard by volcanic source in Jakarta, Indonesia), or for identifying priority areas for more detailed hazard modelling at the local-scale.

This hazard modelling and associated risk results must be considered preliminary; probabilistic consideration of wind conditions is required before incorporating results into hazard or risk decision making. 
Volcanic risk assessment is still in its infancy compared to other natural hazards, such as earthquake and tropical cyclone. Our knowledge regarding the impacts of ash fall are constrained to anecdotal evidence and a relatively small number of post-event investigations. Over the rest of this section we highlight some of the key advancements that may be expected in the coming years, including improved knowledge of exposure relevant to volcanic hazards, better understanding the vulnerability of these exposed communities and assets, and advances in modelling hazard dynamics and intensity.

\subsection{Better understanding of hazard}

When considering natural hazards in general, the success of hazard and risk assessment rests on the availability, resolution and accuracy of relevant data. In terms of ash fall hazard, geological and historical information describing past events is critical. A comprehensive eruption history allows time-dependent probabilities for various eruptive styles and magnitudes to be most accurately determined. While geological studies mean that it is possible to improve the understanding of eruptive activity for individual volcanoes, it is difficult to improve eruption history greatly at the global level. Improvements in global hazard assessment will therefore largely come from collation of volcano-specific eruption and environmental (i.e. meteorological and topographic) information into comprehensive databases (e.g. Global Volcanism Program (GVP): volcano.si.edu; Large Magnitude Explosive Volcanic Eruptions: bgs.ac.uk/vogripa; Global Volcano Model (GVM): globalvolcanomodel.org; NCEP/NCAR wind Reanalysis: esrl.noaa.gov/psd/data/reanalysis/reanalysis.shtml; ERA-Interim wind Reanalysis: ecmwf.int/en/research/climatereanalysis/era-interim), in-depth statistical analysis of these databases, development of increasingly sophisticated modelling techniques and more advanced computing resources. Each new explosive eruption provides a calibration opportunity for ash dispersal models and, with an understanding of the underlying physics, can lead to improvements in model accuracy. Models are thus tested against an increasing set of input scenarios, which with time will make them more applicable to a range of eruption styles and environmental conditions.

\subsection{Increased exposure information}

For ash fall risk assessment, relevant exposure information includes the spatial distributions of population, demographics, building types, infrastructure and land usage. To best assess potential impacts, the location and characteristics of exposed elements should be included at the same scale as the modelled hazard. Improvements in satellite and ground-based acquisition and improved availability of local geo-referenced databases will mean that we will see continued improvement in this area, which can be carried through into future risk assessments. In particular, the development of automated image recognition tools and rapid and remote data collection will likely expand the availability, coverage and accuracy of exposure information. Global exposure datasets are improving rapidly with a growing trend towards open-source information (e.g. OpenStreetMap: openstreetmap.org; UNEP-GRID: grid.unep.ch).

At the local level, inventories can be developed that record the numbers, distribution and characteristics (with respect to their vulnerability to volcanic hazards) of exposed assets. Standardised field survey methodologies exist for assessing building stock (e.g. Spence et al., 1996; Marti et al., 2008; Jenkins et al., 2014), but structured field survey methods for infrastructure are more difficult due to security concerns and the wide variability in network design, type and dependencies. However, assessing the characteristics of vulnerable items, as well as their dependency upon other networks, will be a step forward in the absence of detailed exposure information.

\subsection{Improved understanding of impacts and associated vulnerability}

Recent empirical, experimental and theoretical studies have greatly improved our understanding of the physical response of elements to ash fall. However, systematic and comprehensive documentation of observed impacts, including cascading impacts, under a wide range of ash fall conditions is lacking. For example, studies have typically not focused on impacts associated with thin $(<2 \mathrm{~mm})$ ash falls, but on large eruptions and impacts associated with ash falls of more than $10 \mathrm{~mm}$ thickness. Thin, distal ash falls of a few $\mathrm{mm}$ or less are therefore a source of significant uncertainty for emergency management planning and loss assessment models, despite being the volcanic hazard 
most likely to be experienced by exposed critical infrastructure (Wilson et al., 2012b). In future damaging ash fall events, quantitative impact studies will be critical in supplementing the sparse existing empirical data set and for calibrating existing vulnerability estimates obtained through experimental and theoretical studies. To enable damaging events to be compared, standard data collection guidelines should be followed, for example the ash collection and analysis protocols promoted by the International Volcanic Health Hazard Network (ivhhn.org) and the building survey guidelines discussed in Section 5.2.

While post-eruption impact assessment studies will continue to strengthen and diversify our understanding of ash fall impacts, this reactive research model rarely allows for detailed analysis to determine with any certainty how and why observed impacts occurred. There is a lack of empirical knowledge regarding how ash properties such as abrasiveness and corrosiveness affect critical infrastructure components over varying timescales. Understanding how the geotechnical properties and surface chemistry of ash influences impacts to societal elements is a current gap in understanding, although there are exciting developments in the human health field. However, it is difficult to explore impact thresholds in the field due to difficulties in obtaining timely access, limited field time, variations in environmental conditions and incomplete ranges of ash characteristics such as thickness, grain size and surface coating composition. One solution is empirical performance testing of critical components using varying intensities, types and compositions of ash under laboratory conditions. This allows performance thresholds to be assessed for different configurations of equipment and different characteristics of ash fall. Crucially, it also provides a setting for proactive experimentation of potential mitigation methods.

In addition to empirical data sourced from impact assessments and experimental testing of critical components, developments in numerical impact and risk modelling (e.g. Magill et al., 2006; Spence et al., 2008; Zuccaro et al., 2008; Scaini et al., 2014) will allow us to test the effects of mitigation options and explore uncertainties in risk rapidly and in the absence of an actual eruption. Expert judgement focus groups (e.g. Aspinall and Cooke, 2013) can be useful in better quantifying components of risk where large uncertainty is present, for example the probability of an explosive eruption occurring.

\section{Final words}

Ash fall is the most widespread and frequent of the hazards posed by volcanic eruptions. A comprehensive volcanic hazard assessment must include ash fall in addition to more localised hazards such as pyroclastic density currents. However, the impacts of ash fall are arguably more complex and multi-faceted than for any of the other volcanic hazards and for that reason the GVM/IAVCEI contribution to GAR-15 includes a technical background paper dedicated solely to the hazard and risk posed by ash fall. Within this paper, a summary review of some approaches to volcanic ash fall hazard and risk assessment has been provided, elaborating on two ash fall hazard assessments that have been undertaken at the global and local scale (Section 3). In discussing how these hazard studies may be translated to risk, the key characteristics and likely impacts of ash fall for society have been highlighted (Section 4). Elements of society known to be impacted by volcanic ash include human populations, dwellings, infrastructure, aviation, agriculture and/or other economic activities. In this paper we focussed on the vulnerability of these sectors can influence the impacts experienced; we also considered socio-economic impacts and issues surrounding clean-up (Section 5). The ability to adequately quantify risk is clearly dictated by the availability and quality of each set of input data (hazard, exposed elements, vulnerability of these elements). The scarcity of detailed empirical data for ash fall impacts limits our ability to provide definitive assessment of future impacts but ongoing studies for ash fall, and other volcanic hazards, continue to improve our understanding and forecasting ability. 


\section{References}

Aspinall, W.P. and Cooke, R., 2013. Expert Elicitation and Judgement. In: Rougier, J. C., Sparks, R. S. J., Hill, L. (editors) Risk and Uncertainty assessment in Natural Hazards. Cambridge University Press, pp. 234-274.

Auker, M.R., Sparks, R.S.J., Siebert, L., Crosweller, H.S. and Ewert, J., 2013. A statistical analysis of the global historical volcanic fatalities record. Journal of Applied Volcanology, 2:2.

Barberi, F., Macedonio, G., Pareschi, M., Santacroce, R., 1990. Mapping the tephra fallout risk: an example from Vesuvius (Italy). Nature, 344: 142-144.

Barsotti, S., Neri, A. and Scire, J. S., 2008. The VOL-CALPUFF model for atmospheric ash dispersal: 1. Approach and physical formulation. Journal of Geophysical Research: Solid Earth, 113(B03208).

Baxter, P.J., Ing, R., Falk, H., French, J., Stein, G.F., Bernstein, R.S., Merchant, J.A., Allard, J., 1981. Mount St Helens Eruptions, May 18 to June 12, 1980: An Overview of the Acute Health Impact. The Journal of the American Medical Association, 246(22): 2585-2589.

Bear-Crozier, A.N., Miller, V., Newey, V., Horspool, N \& Weber, R., 2014. Emulating volcanic ash fall for multi-scale analysis - Development of the VAPAHR tool and application to the Asia-Pacific region, Geoscience Australia Record 2014/36. http://dx.doi.org/10.11636/Record.2014.036

BGVN, 1980. Bulletin of the Global Volcanism Network: 05/1980 (SEAN 05:05), Major eruption sends cloud to $23 \mathrm{~km}$, destroys summit, and devastates region.

Biass, S., Scaini, C., Bonadonna, C., Folch, A., Smith, K. and Höskuldsson, A., 2014. A multi-scale risk assessment for tephra fallout and airborne concentration from multiple Icelandic volcanoes - Part 1: Hazard assessment. Natural Hazards and Earth Systems Science, 2: 2463-2529.

Blong, R.J., 2003a. A new damage index. Natural Hazards, 30: 1-23.

Blong, R.J., 2003b. Building damage in Rabaul, Papua New Guinea, 1994. Bulletin of Volcanology, 65 (1): 43-54.

Blong, R.J., 1984. Volcanic hazards: a sourcebook on the effects of eruptions. Academic Press Australia, $424 \mathrm{pp}$.

Bonadonna, C. and Costa, A., 2013. Modeling of ash sedimentation from volcanic plumes. In: Fagents, S. A., Gregg, T. K. P. and Lopes, R. M. C., Modeling Volcanic Processes: The Physics and Mathematics of Volcanism. Cambridge University Press. ISBN: 9780521895439.

Bonadonna, C. and Costa, A., 2012. Estimating the volume of tephra deposits: a new simple strategy. Geology 40(5):415418.

Bonadonna, C., 2006. Probabilistic modelling of tephra dispersal. In: Mader, H., Cole, S. and Connor, C.B. (editors) Statistics in Volcanology. IAVCEI Series Volume 1, Geological Society of London, pp 243-259.

Brown, S.K., Loughlin, S.C., Sparks, R.S.J. and Vye-Brown, C. 2014. Global volcanic hazards and risk. Technical Report for the UNISDR 2015 Global Assessment Report on Disaster Risk Reduction.

Buteler, M., Stadler, T., Lopez Garcia, G.P., Lassa, M.S., Trombotto Liaudat, D., D'Adamo, P. and Fernandez-Arhex, V. (2011) Propiedades insecticidas de la ceniza del complejo volcánico Puyehue-Cordón Caulle y su possible impacto ambiental. Revista de la Sociedad Entomológica Argentina. 70 (3-4), 149-156.

ByMur 2010-2014, Bayesian Multi-risk Assessment: a case study for the Natural Risks in the city of Naples, http://bymur.bo.ingv.it/

Carey, S. and Sigurdsson, H., 1989. The intensity of Plinian eruptions. Bulletin of Volcanology, 51(1): 28-40.

Carlsen, H.K., Gislason, T., Benediktsdottir, B., Kolbeinsson' T.B., Hauksdottir, A., Thorsteinsson' T. and Briem, H., 2012a. A survey of early health effects of the Eyjafjallajökull 2010 eruption in Iceland: a population-based study. BMJ Open, 2: e000343.

Carlsen, H.K., Hauksdottir, A., Valdimarsdottir, U.A., Gislason, T., Einarsdottir, G., Runolfsson, H., Briem, H., Finnbjornsdottir, R.G., Gudmundsson, S., Kolbeinsson' T.B., Thorsteinsson' T. and Pétursdóttir, G., 2012b. Health effects following the Eyjafjallajökull volcanic eruption: a cohort study. BMJ Open, 2: e001851.

CIMNE, SAS, I., LTDA, I. and SA, E., 2013. Probabilistic modelling on natural risks at the global level: Global Risk Model 2013, Geneva, Switzerland: UNISDR.

Cioni, R., Longo, A., Macedonio, G., Santacroce, R., Sbrana, A., Suplizio, R. and Andronico, D., 2003. Assessing pyroclastic fall hazard through field data and numerical simulations: example from Vesuvius. Journal of Geophysical Research, 108:2063.

Cook, R.J., Barron, J.C., Papendick, R.I. and Williams, G.J., 1981. Impact on agriculture of the Mount St. Helens eruptions, Science, 211, 16-22.

Costa, A., Dell'Erba, F., Di Vito, M.A., Isaia, R., Macedonio, G., Orsi, G. and Pfeiffer, T., 2009. Tephra fallout hazard assessment at the Campi Flegrei caldera (Italy). Bulletin of Volcanology, 71: 259-273.

Cronin, S.J., Hedley, M.J., Neall, V.E. and Smith, R.G., 1998. Agronomic impact of ash fallout from the 1995 and 1996 Ruapehu Volcano eruptions, New Zealand, Environmental Geology, 34(1), 21-30.

De Bono, A., 2013. The Global Exposure Database for GAR 2013, Geneva, Switzerland: UNISDR. 
De Lima, E.F., Sommer, C.A., Cordeiro Silva, I.M., Netta, A.P., LIndenberg, M. and Marques Alves, R. de C., 2012. Morfologia e quimica de cinzas do vulcão Puyehue depositadas na região metropolitana de Porto Alegre em junho de 2011. Revista Brasiliera de Geociências, 42(2): 265-280.

Delmelle, P., Lambert, M., Dufrêne, Y., Gerin, P. and Óskarsson, N., 2007. Gas/aerosol-ash interaction in volcanic plumes: New insights from surface analyses of fine ash particles. Earth and Planetary Science Letters, 259(1-2): 159-170.

Dilley, M., Chen, R. S., Deichmann, U., Lerner-Lam, A. L., Arnold, M., Agwe, J., Buys, P., Kjekstad, O., Lyon, B. and Yetman, G., 2005. Natural disaster hotspots: a global risk analysis, International Bank for Reconstruction and Development/The World Bank and Columbia University.

DPC-V1 2012-2013: Valutazione della pericolosità vulcanica in termini probabilistici, http://istituto.ingv.it/lingv/progetti/progetti-finanziati-dal-dipartimento-di-protezione-civile-1/progetti-vulcanologici-2012

DPC-V2 2012-2014: Precursori di eruzioni, http://istituto.ingv.it/l-ingv/progetti/progetti-finanziati-dal-dipartimento-diprotezione-civile-1/progetti-vulcanologici-2012

Durand, M., Gordon, K., Johnston, D.M., Lordon, R., Poirot, T., Scott, J. and Shepard, B., 2001. Impacts of, and responses to, ash fall in Kagoshima from Sakurajima Volcano - Lessons for New Zealand. Institute of Geological \& Nuclear Sciences Science Report 2001/30, 53p.

Durant, A.J., Rose, W.I., Sarna-Wojcicki, A.M., Carey, S. and Volentik, A.C.M., 2009. Hydrometeor-enhanced tephra sedimentation: Constraints from the 18 May 1980 eruption of Mount St. Helens. Journal of Geophysical Research, 114: $2 \mathrm{pp}$.

EC MEDSUV, 2013-2015: MEDiterranean SUpersite Volcanoes,http://ec.europa.eu/research/environment/geo/pdf/ supersites/medsuv-puglisi.pdf

Folch, A. and Sulpizio, R., 2010. Evaluating long-range volcanic ash hazard using supercomputing facilities: application to Somma-Vesuvius (Italy), and consequences for civil aviation over the Central Mediterranean Area. Bulletin of Volcanology, 72: 1039-1059

Gaillard, J. C. 2006. Traditional societies in the face of natural hazards: the 1991 Mt.Pinatubo eruption and the Aetas of the Philippines. International Journal of Mass Emergencies and Disasters, 24, 1, 5-43.

Galderisi, A., Bonadonna, C., Delmonaco, G., Ferrara, F.F., Menoni, S., Ceudech, A. Biass, S., Frischkcecht, C., Manzella, I., Minucci, G. and Gregg, C., 2013. Vulnerability assessment and risk mitigation: The case of Vulcano Island, Italy. In: Margottini, C., Canuti, P. and Sassa, K. (Editors), Landslide Science and Practice. Springer-Verlag, 7: 55-64.

Heffter, J. L. and Stunder, B. J. B., 1993. Volcanic Ash Forecast Transport and Dispersion (VAFTAD) Model. Weather and Forecasting, 8: 533-541.

Horwell, C. J. and Baxter, P. J., 2006. The respiratory health hazards of volcanic ash: a review for volcanic risk mitigation. Bulletin of Volcanology, 69: 1-24

Hurst, A. W., 1994. ASHFALL, a computer program for estimating volcanic ash fallout. GNS Science.

IATA , 2010. Volcano Crisis Cost Airlines \$1.7 Billion in Revenue - IATA Urges Measures to Mitigate Impact. Press Release No. 15. Date: 21 April 2010

Jenkins, S.F., Spence, R.J.S., Fonseca, J.F.B.D., Solidum, R.U. and Wilson, T.M., 2014. Volcanic risk assessment: Quantifying physical vulnerability in the built environment. Journal of Volcanology and Geothermal Research, 276: $105-120$.

Jenkins, S.F., Magill, C,R,, McAneney, K.J., Blong, R., 2012a. Regional ash fall hazard I: A probabilistic assessment methodology. Bulletin of Volcanology 74(7): 1699-1712.

Jenkins, S.F., McAneney, K.J., Magill, C,R, Blong, R., 2012b. Regional ash fall hazard II: Asia-Pacific modelling results and implications. Bulletin of Volcanology 74(7): 1713-1727.

Jenkins S. F., Magill C. R. and McAneney K. J., 2007. Multi-stage volcanic events: A statistical investigation. Journal of Volcanology and Geothermal Research, 161(4): 275-288.

Johnston, D.M., Houghton, B.F., Neall, V.E., Ronan, K.R. and Paton, D., 2000. Impacts of the 1945 and $1995-1996$ Ruapehu eruptions, New Zealand: An example of increasing societal vulnerability. Geological Society of America Bulletin, 112(5): 720-726.

Lahey, K., 2012. No volcanic ash clouds to rain on Australia's parade. The Australian Journal of Emergency Management, 27(1): 16-19.

Macedonio, G. and Costa, A., 2012. Rain effect on the load of tephra deposits. Natural Hazards and Earth System Sciences: Brief Communication, 12: 1229-1233.

Macedonio, G., Costa, A. and Folch, A., 2008. Ash fallout scenarios at Vesuvius: numerical simulations and implications for hazard assessment. Journal of Volcanology and Geothermal Research, 178: 366-377.

Macedonio, G., Pareschi, M. T. and Santacroce, R., 1988. A numerical simulation of the Plinian Fall Phase of 79 A.D. eruption of Vesuvius. Journal of Geophysical Research, 93(B12): 14817-14827.

Magill, C., Wilson, T.M. and Okada, T., 2013. Observations of ash fall impacts from the 2011 Shinmoedake eruption, Japan. Earth, Planets and Space 65(6): 677-698.

Magill, C., Blong, R. and McAneney, J., 2006. VolcaNZ - A volcanic loss model for Auckland, New Zealand. Journal of Volcanology and Geothermal Research, 149(3-4): 329-345. 
Maqsood, T., Wehner, M., Ryu, H., Edwards, M., Dale, K. and Miller, V., 2014. GAR15 Vulnerability Functions. Geoscience Australia Record 2014/38. http://dx.doi.org/10.11636/Record.2014.038

Marti, J., Spence, R., Calogero, E., Ordoñez, A., Felpeto, A. and Baxter, P., 2008. Estimating building exposure and impact to volcanic hazards in Icod de los Vinos, Tenerife (Canary Islands). Journal of Volcanology and Geothermal Research, 178(3): 553-561.

Marzocchi, W., Sandri, L. and Selva, J., 2010. BET_VH: a probabilistic tool for long-time volcanic hazard assessment. Bulletin of Volcanology, 72: 705-716.

Marzocchi, W., Sandri, L. and Selva, J., 2008. BET_EF: a probabilistic tool for long- and short-term eruption forecasting. Bulletin of Volcanology, 70: 623-632.

Marzocchi, W., Sandri, L., Gasparini, P., Newhall, C. and Boschi, E., 2004. Quantifying probabilities of volcanic events: the example of volcanic hazard at Mount Vesuvius. Journal of Geophysical Research, 109:B11201.

Mead, S. R. and Magill, C., 2014. Determining change points in data completeness for the Holocene eruption record. Bulletin of Volcanology, 76:874.

Meheux, K., Dominey-Howes, D., Lloyd, K., 2007. Natural hazard impacts in small island developing states: a review of current knowledge and future research needs. Natural Hazards 40, 429-446

Munich-Re, 2007. Volcanism - Recent findings on the risk of volcanic eruptions, Schadenspiegel, 1, pp 34-39

Newhall, C. G. and Hoblitt, R. P., 2002. Constructing event trees for volcanic crises. Bulletin of Volcanology, 64(1): 3-20.

Newhall, C.G., Punongbayan, R.S., 1996. Fire and Mud. Philippine Institute of Volcanology and Seismology, Quezon City and University of Washington Press, Seattle and London.

Newhall, C., Self, S., 1982. The volcanic Explosivity Index (VEI): An estimate of explosive magnitude for historical volcanism. Journal of Geophysical Research, 87: 1231-1238.

Orsi, G., di Vito, M.A., Selva, J. and Marzocchi, W., 2009. Long-term forecast of eruption style and size at Campi Flegrei caldera (Italy). Earth and Planetary Science Letters, 287: 265-276.

Oze, C., Cole, J.W., Scott, A., Wilson, T.M., Wilson, G., Gaw, S., Hampton, S.J., Doyle, C. and Li, Z., 2014. Corrosion of metal roof materials related to volcanic ash interactions. Natural Hazards, 71: 785-802.

Pyle, D.M. 1989. The thickness, volume and grain size of ash fall deposits. Bulletin of Volcanology, 51: 1-15.

Ronan, K.R., 1997, The effects of a "benign" disaster: Symptoms of post-traumatic stress in children following a series of volcanic eruptions. Australasian Journal of Disaster and Trauma Studies, 1.

Ryall, D. B. and Maryon, R. H., 1998. Validation of the UK Met. Office's NAME model against the ETEX dataset. Atmostpheric Environment, 32: 4265-4276.

Sandri, L., Thouret, J.-C., Constantinescu, R., Biass, S. and Tonini, R., 2014. Long-term multi-hazard assessment for El Misti volcano (Peru). Bulletin of Volcanology, 76(2): 1-26.

Sandri, L., Jolly, G., Lindsay, J., Howe, T. and Marzocchi, W., 2012. Combining long- and short-term probabilistic volcanic hazard assessment with cost-benefit analysis to support decision making in a volcanic crisis from the Auckland Volcanic Field, New Zealand. Bulletin of Volcanology, 74: 705-723.

Sarna-Wojcicki, A. M., Shipley, S., Waitt Jr., R. B., Dzurisin, D., Wood, S. H., Lipman, P. W. \& Mullineaux, D. R. 1981. Areal distribution, thickness, mass, volume, and grain size of air-fall ash from the six major eruptions of 1980 . In: Lipman, P. W. \& Mullineaux, D. R. (eds.) The 1980 Eruptions of Mount St. Helens, Washington. U.S. Geological Survey Professional Paper.

Scaini, C., Felpeto, A., Marti, J. and Carniel, R., 2014. A GIS-based methodology for the estimation of potential volcanic damage and its application to Tenerife Island, Spain. Journal of Volcanology and Geothermal Research, 278: 4058.

Scasso, R.A., Corbella, H. and Tiberi, P., 1994. Sedimentological analysis of the tephra from the 12-15 August 1991 eruption of Hudson volcano. Bulletin of Volcanology, 56: 121-132.

Selva, J. and Sandri, L., 2013. Probabilistic Seismic Hazard Assessment: Combining Cornell-like approaches and data at sites through Bayesian inference. Bulletin of the Seismological Society of America, 103(3): 1709-1722.

Selva, J., Orsi, G., Di Vito, M.A., Marzocchi, W., and Sandri, L., 2012. Probability hazard map for future vent opening at the Campi Flegrei caldera, Italy. Bulletin of Volcanology, 74: 497-510.

Selva, J., Costa, A., Marzocchi, W. and Sandri, L., 2010. BET_VH: exploring the influence of natural uncertainties on longterm hazard from tephra fallout at Campi Flegrei (Italy). Bulletin of Volcanology, 72: 717-733.

Simkin T., Siebert L. and Blong R., 2001. Disasters: Volcano Fatalities-Lessons from the historical Record. Science, 291 (5502): 255-255.

Small C. and Naumann T., 2001. The global distribution of human population and recent volcanism. Environmental Hazards 3(3/4): 93-109.

Sparks, R., Bursik, M., Ablay, G., Thomas, R. and Carey, S., 1992. Sedimentation of ash by volcanic plumes. Part 2: controls on thickness and grain-size variations of ash fall deposits. Bulletin of Volcanology, 54: 685-695.

Spence, R., Komorowski, J.-C., Saito, K., Brown, A., Pomonis, A., Toyos, G. and Baxter, P., 2008. Modelling the impact of a hypothetical sub-Plinian eruption at La Soufrière of Guadeloupe (Lesser Antilles). Journal of Volcanology and Geothermal Research, 178(3): 516-528. 
Spence, R., Kelman, I,, Baxter, P., Zuccaro, G. and Petrazzuoli, S., 2005. Residential building and occupant vulnerability to tephra fall. Natural Hazards and Earth Systems Science, 5: 477-494.

Spence, R., Pomonis, A., Baxter, P., Coburn, A., White, M. and Dayrit, M., Field Epidemiology Training Program Team., 1996. Building damage caused by the Mount Pinatubo eruption of June 15, 1991. In: C.G. Newhall, R.S. Punongbayan (Editors), Fire and Mud: eruptions and lahars of Mount Pinatubo, Philippines, Philippines Institute of Volcanology and Seismology, University of Washington Press, Seattle, 1055-1061.

SSHAC (Senior Seismic Hazard Analysis Committee), 1997. Recommendations for probabilistic seismic hazard analysis: Guidance on uncertainty and use of experts. Technical Report, NUREG/CR-6372, U.S. Nuclear Regulatory Commission, Washington, D. C.

Stewart, C., Horwell, C., Plumlee, G., Cronin, S.J., Delmelle, P., Baxter, P., Calkins, J., Damby, D., Morman, S. and Oppenheimer, C. (2013) Protocol for analysis of volcanic ash samples for assessment of hazards from leachable elements. IVHHN Report ratified by IAVCEI, Cities and Volcanoes Commission, USGS and GNS Science. Available at: www.ivhhn.org.

Suzuki, T., 1983. A theoretical model for dispersion of ash. In: Shimozuru, D. and Yokohama, I. (Editors), Arc volcanism: physics and tectonics. Terra Scientific Publishing, Tokyo, 95-113.

Sword-Daniels, V., Wilson, T.M., Sargeant, S., Rossetto, T., Twigg, J., Johnston, D.M., Loughlin, S.C. and Cole, P.D., 2014. Consequences of long-term volcanic activity for essential services in Montserrat: challenges, adaptations and resilience. In: Memoir of the Geological Society of London Special volume "The Eruption of Soufriere Hills".

Walker, G., 1981. Plinian eruptions and their products. Bulletin of Volcanology, 44(3): 223-240.

Wilson, L. and Walker, G.P.L., 1987. Explosive volcanic eruptions - VI. Ejecta dispersal in plinian eruptions: the control of eruption conditions and atmospheric properties. Geophysical Journal International, 89(2): 657-679.

Wilson, T.M., Stewart, C., Bickerton, H., Baxter, P.J., Outes, V., Villarosa, G. and Rovere, E., 2012a, Impacts of the June 2011 Puyehue Cordón-Caulle volcanic complex eruption on urban infrastructure, agriculture and public health. GNS Science. 88p.

Wilson, T.M., Stewart, C., Sword-Daniels, V., Leonard, G.S., Johnston, D.M., Cole, J.W., Wardman, J., Wilson, G. and Barnard, S.T., 2012b. Volcanic ash impacts on critical infrastructure. Physics and Chemistry of the Earth, 45-46: 523.

Wilson, T., Cole, J., Stewart, C., Cronin, S. and Johnston, D., 2011. Ash storms: impacts of wind-remobilised volcanic ash on rural communities and agriculture following the 1991 Hudson eruption, southern Patagonia, Chile. Bulletin of Volcanology, 73(3): 223-239.

Wisner, B., Gaillard, J. \& Kelman, I. (Eds.). 2012. The handbook of hazards and disaster risk reduction, Routledge, Oxon.

Witham, C., 2005. Volcanic disasters and incidents: a new database. Journal of Volcanology and Geothermal Research, 148: 191-233.

Woods, A. W. and Bursik, M. I., 1991. Particle fallout, thermal disequilibrium and volcanic plumes. Bulletin of Volcanology, 53: $559-570$.

Yokoyama I., Tilling R. I. and Scarpa R., 1984. International mobile early-warning system(s) for volcanic eruptions and related seismic activities, FP/2106-82-01 (2286), UNESCO, Paris.

Zuccaro, G., Cacace, F., Spence, R.J.S. and Baxter, P.J., 2008. Impact of explosive eruption scenarios at Vesuvius. Journal of Volcanology and Geothermal Research, 178(3): 416-453. 
Department of Industry

Minister for Industry: The Hon Ian Macfarlane MP

Parliamentary Secretary: The Hon Bob Baldwin MP

Secretary: Ms Glenys Beauchamp PSM

\section{Geoscience Australia}

Chief Executive Officer: Dr Chris Pigram

This paper is published with the permission of the CEO, Geoscience Australia

Geoscience Australia's participation in this work was funded by the Australian Department of Foreign Affairs and Trade.

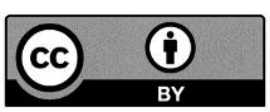

(C) Commonwealth of Australia (Geoscience Australia) 2014

With the exception of the Commonwealth Coat of Arms and where otherwise noted, all material in this publication is provided under a Creative Commons Attribution 3.0 Australia Licence.

(http://www.creativecommons.org/licenses/by/3.0/au/deed.en) 

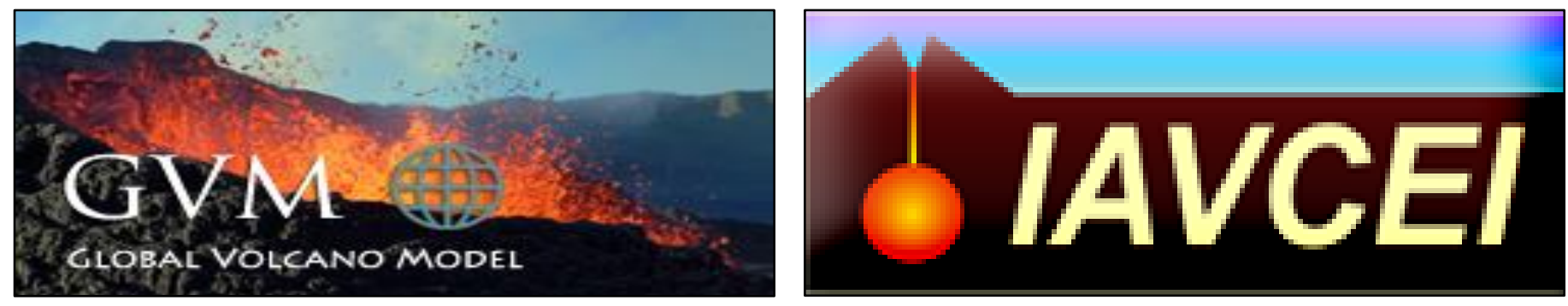

\section{Technical Background Paper prepared for the UNISDR 2015 \\ Global Assessment Report on Disaster Risk Reduction}

The Global Volcano Model (GVM) is a growing international network that aims to create a sustainable, accessible,

information platform on volcanic hazard and risk. GVM will provide systematic evidence, data and analysis of volcanic hazards and risk on global and regional scales, and support Volcano Observatories at a local scale. GVM will develop capabilities to anticipate future volcanism and its consequences.

\section{www.GlobalVolcanoModel.org}

The International Association of Volcanology and Chemistry of the Earth's Interior (IAVCEI) represents the primary international focus for: (1) research in volcanology, (2) efforts to mitigate volcanic disasters, and

(3) research into closely related disciplines. There are 22 topic focussed Commissions of IAVCEI covering all aspects of volcanology, including hazards and risk.

www.iavcei.org

Please cite this Technical Background Paper as:

Jenkins, S.F., Wilson, T.M., Magill, C.R., Miller, V., Stewart, C., Marzocchi, W. and Boulton, M., 2015. Volcanic ash fall hazard and risk: Technical Background Paper for the UNISDR 2015 Global Assessment Report on Disaster Risk Reduction. Global Volcano Model and IAVCEI.

http://www.preventionweb.net/english/hyogo/gar. 